Niniejsza publikacja jest dostęna na licencji Creative Commons. Uznanie autorstwa-Użycie niekomercyjne-Bez utworów zależnych 3.0 Polska. Pewne prawa zastrzė̇one na rzecz autora. Zezwala się na wykorzystanie publikacji zgodnie z licencja - pod warunkiem zachowania niniejszej informacji licencyjnej oraz wskazania autora jako właściciela praw do tekstu. Treść licencji jest dostępna na stronie: http://creativecommons.org/licenses/by-nc-nd/3.0/pl/

Lingwistyka Stosowana 20: 5/2016, 127-154

\author{
Malgorzata SZUPICA-PYRZANOWSKA \\ Uniwersytet Warszawski
}

\title{
Przetwarzanie fleksji języka angielskiego w czasie rzeczywistym - badanie eyetrackingowe
}

\begin{abstract}
:
English inflectional processing in real time - evidence from eyetracking

The present study takes morphosyntactic processing one step further and investigates advanced foreign learners' sensitivity to morphosyntactic errors and correct forms of various complexity in an online reading task. Consequently, the following research questions are postulated: (1) Are advanced foreign language learners sensitive to morphosyntactic violations/correct forms of different complexity (e.g. genitive possessive, plural, past tense, subject-verb agreement)? (2) Do inflectional errors of different complexity generate different fixation patterns as compared to correct forms? (3) Do eye movements index morphosyntactic complexity? Is eye tracking an appropriate measure to test the comprehension of morphosyntactic violations?

The morphosyntactic processing was investigated in sentential contexts. The target lexical items were controlled for sentence position on the screen, word length, number of words in target sentences, lexical frequency, and second constituent frequency in case of genitive possessive. There were no explicit task demands. The participants $(\mathrm{N}=35)$ were asked to silently read the sentences for comprehension at their natural pace. We used the SMI RED eye tracker with a good temporal resolution and a sampling rate of $250 \mathrm{~Hz}$. Sums of dwell time, fixation durations, and fixation time were averaged across participants. There was a significant difference between the correct and incorrect forms. The analysis reveals that not only inflectional errors but also correct forms were challenging for the parser as inflected forms generated longer fixations. The direction was not as predicted, though. Also, the participants parsed genitive possessive longer than its inflectional counterparts. Regarding the appropriateness of eye tracking to test morphosyntactic processing, we state that the results obtained suggest the course of further explorations.
\end{abstract}

\section{Wstęp}

Proces przyswajania języka obcego/drugiego jest od lat przedmiotem licznych badań lingwistycznych jaki i psycholingwistycznych. Jednakże, pomimo znacznych postępów, nie wszystkie mechanizmy odpowiedzialne za przetwarzanie języka obcego/drugiego są w pełni znane. Na przykład, ciągle jeszcze niedostatecznie rozumiemy, czy osoby posługujące się obcym/ drugim językiem na poziomie zaawansowanym przy przetwarzaniu jego struktur morfosyntaktycznych stosują strategie podobne do tych, których używają rodzimi użytkownicy tego języka. Dotychczas zajmowano się tymi zagadnieniami stosując metody behawioralne, np. pomiar czasu czytania i słuchania, ewaluacje poprawności gramatycznej, czy pomiar czasu reakcji. 
Niestety metody te okazują się niewystarczające, ponieważ oceniają one wyłącznie reakcje na struktury języka obcego/drugiego po czasie rzeczywistym (off-line), czyli rejestrują jedynie skutek reakcji, a nie samą reakcję na bodziec wtedy, kiedy ona zachodzi. Uczestnicy wyżej wymienionych eksperymentów często stosują rożne strategie kompensacyjne, które maskują rzeczywiste przetwarzanie języka. Z tego powodu behawioralny model eksperymentalny typu off-line nie zapewnia możliwości dokładnego prześledzenia przebiegu przetwarzania procesów morfosyntaktycznych w akwizycji języka obcego/drugiego. W tym celu niezbędne jest wykorzystywanie metod umożliwiających wnikliwszą analizę rożnych komponentów rozumienia języka w czasie rzeczywistym (online); do metod takich zaliczane są między innymi badania okulograficzne, które rejestrują i analizują aktywność i położenie gałki ocznej.

\section{Morfoskładnia języka angielskiego - charakterystyka i wyzwania}

Szczątkowy charakter paradygmatu fleksyjnego języka angielskiego, zawierający cztery fleksyjne formy czasownikowe oraz rzeczownikowe, nie powinien stanowić wyzwania dla jego użytkowników, rodzimych bądź nie:

AGR (-s) związek zgody John likes his new bike.

PAST (-ed) czas przeszły John liked his old bike, too.

PLU (-s) liczba mnoga John always had fast bikes.

POSS ('s) forma dzierżawcza John's new bike is also fast.

Jednakże, zgromadzone dowody wydaję się temu przeczyć. Niekonsekwencja w stosowaniu form fleksyjnych została szczegółowo udokumentowana w kontekście akwizycji języka drugiego (zob. R. Bayley 1996, S.D. Epstein/ S. Flynn/ G. Martohardjono 1996, H. Goad/ L. White/ J. Steel 2003, E. Klein i in. 2003, D. Lardiere 1998a, 1998b, 2000, P. Prèvost/ L. White 2000). Nawet zaawansowani uczniowie angielskiego jako języka drugiego używają form fleksyjnych niepoprawnie (zob. R. Hawkins 2000, D. Lardiere 1998, 2000, L. White 2003, 2008):

\section{Czas przeszly}

I never saw them before; they open my brain.

(rodzimy użytkownik języka chińskiego)

They pick me up and they brought me in their spaceship.

(rodzimy użytkownik języka francuskiego)

\section{Związek zgody}

Mary gets up at 6 o'clock every morning. And then she clean her teeths and her face. (rodzimy użytkownik języka chińskiego)

She's really sleepy so she goes to bed and read a little bit and at 10:45 she turn off the light and go to bed.

(rodzimy użytkownik języka francuskiego) (zob. L. White 2008: 316) 
Powyższe przykłady ilustrują skalę niekonsekwentnego użycia fleksji. Formy poprawne i błędne występują $\mathrm{w}$ nich obok siebie nawet $\mathrm{w}$ ramach tego samego zdania. Ponadto błędy fleksyjne $\mathrm{w}$ języku angielskim popełniają nie tylko ci uczniowie, których język rodzimy nie jest językiem fleksyjnym (np. chiński), ale i ci, których język ojczysty zawiera w swoim repertuarze składniowym zarówno czas przeszły, jak i związek zgody (np. francuski). Brak spójności w stosowaniu zasad fleksji języka drugiego ma miejsce, pomimo, że fleksja jest obecna w języku, który słyszą uczący się go. Deficytem fleksyjnym charakteryzują się również wypowiedzi rodzimych użytkowników języka angielskiego cierpiący na afazję Broki (zob. M. Arabatzi/ S. Edwards 2000, 2002, R. Bastiaanse/ C.K. Thompson 2003, Y. Grodzinsky 2000, L. Menn/ L.K. Obler 1990, M. Wenzlaff/ H. Clahsen 2004). Brak form fleksyjnych bądź zastępowanie jednych form drugimi jest jedną z głównych cech agramatyzmu. Poniższe przykłady są dowodem na to, że nawet łagodnie upośledzeni pacjenci z afazją Broki wykazują agramatyczną produkcję mowy:

My mother died uh (...) I guess six month my mother pass away.

(zob. W. Badecker/ A. Caramazza 1985)

My husband $u h . . . h e . . . u h . .$. he...play ...uh...sports.

(Personalna komunikacja z BK 2007)

Wyzwania jakie stawia przed użytkownikiem fleksja angielska najwyraźniej widać na przykładzie formy dzierżawczej, na podstawie którego przedstawimy pełne spektrum trudności związanych $\mathrm{z}$ fleksją angielską. Po pierwsze, nawet rodzimi użytkownicy języka angielskiego niepoprawnie stosują dopełniacz dzierżawczy (POSS) używając go w kontekście nieprzeznaczonym dla tej formy, np. Reader's will be stunned at the overwhelming evidence of sexism the author's provide (zob. C. Larson 1998) lub go pomijają jak ma to miejsce w afro-amerykańskim dialekcie języka angielskiego, I met his brother wife. lub His cat name is Peanut (zob. S. Ash/ J. Myhill 1986). Po drugie, forma dzierżawcza pojawia się późno w procesie akwizycji zarówno u dzieci uczących się angielskiego, jako języka pierwszego jak i u dzieci i dorosłych, dla których angielski jest językiem drugim lub obcym (zob. H.C. Dulay/ M.K. Burt 1974, N. Bailey/ C. Madden/ S.D. Krashen 1974, D.E. Larsen-Freeman 1976, H. Zobl/ J. Liceras 1994, R.W. Andersen 1978, T. Pica 1983, B.J. Mace-Matluck 1979, Y. Nuibe 1986, Z.P. Luk/ Y. Shirai 2009). Nie ma zgodności, co do właściwego porządku, w którym przyswajane są morfemy angielskie. Niemniej jednak wszyscy zajmujący się tym zagadnieniem zgodnie podkreślają, że forma dopełniacza dzierżawczego pojawia się późno. Po trzecie, studenci języków obcych używający języka angielskiego do celów akademickich napotykają trudności w poprawnym stosowaniu tej formy. Potrafią oni, co prawda, właściwie stosować prostsze konstrukcje dzierżawcze (John's book), jednak bardziej złożone jej formy nastręczają problemów (np. the music's beat, our teacher's hobby, one of life's little comforts, the kid next door's imaginary friend). Co więcej, również kandydaci na nauczycieli języka angielskiego niepoprawnie używają formy dzierżawczej np. w kontekście zarezerwowanym dla liczby mnogiej (There are many appropriate listening tasks that train students' to listen effectively.) albo nie przestrzegają zasad mor- 
fofonologicznych regulujących jej poprawne użycie (The song which I have chosen for my students contains the verb "have got" and vocabulary connected with students's favorite things) oraz stosują ją niekonsekwentnie pomijając bądź stosując ją poprawnie $\mathrm{w}$ ramach jednego zdania jak ma to miejsce $\mathrm{w}$ poniższym przykładzie: Therefore, incorporating samples of native speakers speech acts into language curricula may enhance learners' proficiency (Komunikacja personalna 2012).

Kolejność, w której przyswajane są morfemy angielskie (np. AGR, PLU, PAST, POSS) przez osoby uczące się tego języka w różnym wieku, została również zaobserwowana w afazji agramatycznej, czyli rodzaju upośledzenia językowego, którego główną cechą jest naruszanie zasad gramatycznych w wypowiadanych zdaniach i słowach (zob. J.G.de Villiers 1974). Dopełniacz dzierżawczy jest wyzwaniem dla pacjentów z afazją gdyż nie są oni w stanie przyporządkować właściwych relacji syntaktycznych $\mathrm{w}$ następujących wyrażeniach dzierżawczych The trainer's dog is here. oraz The dog's trainer is here. (zob. H. Goodglass/ L. Menn 1985). Teoria afazji nie przedstawia satysfakcjonującego wytłumaczenia tego stanu rzeczy. Według hipotezy regresji dopełniacz dzierżawczy jest używany niepoprawnie z powodu jego późnej akwizycji (zob. R. Jakobson 1961, 1968). L.-M. Kean (1979) zwraca uwagę na strukturalną złożoność formy dzierżawczej tłumacząc, że pacjenci z afazją preferują prostsze formy fleksyjne (np. T, AGR, PLU). M. Szupica-Pyrzanowska (2009) badająca deficyt fleksyjny zarówno wśród osób dorosłych uczących się angielskiego, jako języka drugiego oraz wśród anglojęzycznych pacjentów z agramatyczną afazją zaobserwowała, że w obydwu grupach forma dzierżawcza była generowana najmniej poprawnie. Wyniki badania stoją w opozycji do hipotezy brakującej fleksji powierzchniowej sugerującej, że nie ma powodu, dla którego generowanie i przywoływanie niektórych form fleksyjnych miałoby być trudniejsze (zob. L. White 2008). Jednakże, dalsza część dyskusji dowodzi, iż angielskie formy fleksyjne, pomimo, że identyczne fonologicznie (PLU-s, POSS 's, AGR-s), nie są sobie równe gdyż różnią się stopniem złożoności np. AGR, PAST, PLU tworzone są za pomocą afiksacji, podczas gdy POSS ma wielopłaszczyznowy proces derywacyjny.

Teorie syntaktyczne różnie traktują zagadnienia dopełniacza dzierżawczego. R. Quirk i koledzy (1985) uwypuklają nietypowość formy dzierżawczej podkreślając, że nie jest to klasyczna forma fleksyjna, jaką można znaleźć w innych językach. F. Katamba (1993) kładzie nacisk na syntaktyczną autonomiczność tej formy fleksyjnej mającej swoją własną, ściśle określoną, pozycję na drzewie syntaktycznym. A. Carstairs-McCarthy (2002) zwraca uwagę na fakt, że POSS może być dołączony do bardzo rozbudowanych fraz np. man you met yesterday's bicycle i jako taka należy do syntaktyki, a nie do morfologii. W podobnym tonie A. Radford i współpracownicy (2003) utrzymują, że forma POSS jest często błędnie porównywana z prostszymi formami fleksyjnymi np. PLU. Ponadto A.M. Zwicky (1987) traktuje dopełniacz dzierżawczy, jako przyrostek frazowy, a G. Booij (2005) wyjaśnia, że historycznie był on sufiksem, który ewoluował do miana niezależnej formy prozodycznej, clitic. Niejako kontynuując ideę A.M. Zwicky'ego, A. Scott/ D. Denison/ K. Börjars (2007) dowodzą, że jako przyrostek frazowy dopełniacz dzierżawczy stara się godzić pozornie sprzeczne właściwości; jest on bowiem syntaktycznie motywowany, 
ale morfologicznie przyłączany. To wszystko odróżnia POSS od pozostałych form fleksyjnych (PLU, AGR i PAST) oraz świadczy o jej unikalnej strukturze.

W przeciwieństwie do poprzedników M. den Dikken $(1998,2000)$ w swojej analizie dopełniacza dzierżawczego idzie krok dalej i szczegółowo omawia jego proces derywacyjny. Zwraca on uwagę, że w strukturze podstawowej pierwszy komponent wyrażenia, John's mother, possessum (mother) jest podmiotem frazy celownikowej zawierającej possessor (John). W dalszej części procesu derywacyjnego następuje inwersja, której produktem ubocznym jest linker, łącznik. Pomimo że semantycznie pusty, ustala on syntaktyczne relacje między obydwoma rzeczownikami. Gdyby nie linker, mielibyśmy do czynienia z przypadkową sekwencją John mother. W końcowej fazie derywacji łącznik przekształca się $\mathrm{w}$ 's i w takiej formie występuje w strukturze powierzchniowej. Opisany proces jest wielowymiarowy. Formułujemy hipotezę, że kompleksowość formy dzierżawczej oraz jej nietypowy proces derywacyjny przyczyniają się do niepoprawnego użycia tej formy w procesach akwizycji oraz atrycji, czyli utraty języka (zob. M. Szupica-Pyrzanowska 2009, M. SzupicaPyrzanowska/ L.K. Obler/ G. Martohardjono 2016).

Brak form fleksyjnych stanowi jedną z najczęstszych kategorii błędów popełnianych przez Polaków uczących się języka angielskiego (zob. M. Johnston 1997). Niejednokrotnie ograniczają się oni do użycia nieodmienionych form czasownikowych jak i rzeczownikowych. Nawet zaawansowani uczniowie, reprezentujący różne języki rodzime, bywają niekonsekwentni w stosowaniu angielskich form fleksyjnych (zob. H. Hopp 2015). Dotychczasowe badania behawioralne zajmujące się przetwarzaniem morfosyntaktycznym skupiały się na asymetrii pomiędzy rozumieniem, a stosowaniem form fleksyjnych u dzieci (zob. V.E. Johnson/ J.G. de Villiers/ H.N. Seymour 2005) oraz brakiem pełnej integracji materiału morfosyntaktycznego (fleksyjnego) u dorosłych (zob. N. Jiang 2004, 2007, E. Kaan 2014). Badanie okulograficzne wykorzystujące intermodalny paradygmat preferencji wzrokowej wykazało, że zrozumienie fleksji czasownikowej obserwuje się dopiero około 4 roku życia (zob. O. Brandt/ B. Höhle 2009).

Wśród badań behawioralnych zajmujących się przetwarzaniem morfosyntaktycznym (rozumieniem i używaniem materiału fleksyjnego) na uwagę zasługują V.E. Johnson/ J.G.de Villiers/ H.N. Seymour (2005), którzy badali zdolność rozumienia form fleksyjnych u dzieci uczących się angielskiego jako języka ojczystego. W trakcie badania uczestnicy musieli przyporządkować formy fleksyjne odpowiednim rysunkom. Dzieci w wieku od 3 do 4 lat nie wykazywały wrażliwości na zmianę formy fleksyjnej, podczas gdy pięcio- i sześciolatki właściwie rozumiały różnice między The duck swims on the pond. (sg) (Kaczka pływa po stawie) oraz The ducks swim on the pond. (pl) (Kaczki pływają po stawie). Wyniki badania są zgodne $\mathrm{z}$ tym, co zaobserwowała A. Perez-Leroux (2005) w grupie dzieci uczących się hiszpańskiego, jako języka rodzimego. Młodsza grupa uczestników (od 3,2 lat do 4,5 lat) nie rozumiała różnic między formami fleksyjnymi i oscylowała na granicy przypadku. Natomiast starsze dzieci (4,8-6,6 lat) poprawnie rozumiały różnice fleksyjne (67\%) pomiędzy Nada en el charco. (sg) (Kaczka pływa po stawie) oraz Nadan en el charco. (pl) (Kaczki pływają po stawie). Błędne rozumienie form fleksyjnych w 
eksperymencie, w którym dzieci wieku do 5 lat po usłyszeniu zdania musiały wybrać korespondujący z nim rysunek (zob. V.E. Johnson/ J.G. de Villiers/ H.N. Seymour 2005, A. Perez-Leroux 2005) stoi w opozycji do poprawnego używania form fleksyjnych w grupie od 2 do 4 lat (zob. R. Brown 1973, M.L. Rice/ K. Wexler 2002). Innymi słowy, w ww. badaniach widoczna jest asymetria pomiędzy rozumieniem a używaniem form fleksyjnych zarówno $w$ angielskim jak i hiszpańskim.

W celu uzyskania pełniejszego zrozumienia procesów motywujących przetwarzanie morfoskładniowe, O. Brandt/ B. Höhle (2009) próbowały dociec, czy zastosowanie innej metody, czyli takiej, która rejestruje przetwarzanie materiału językowego w czasie rzeczywistym (badania okulograficznego) przyczyni się do zaobserwowania wcześniejszego rozumienia form fleksyjnych $\mathrm{w}$ języku niemieckim od tego zaobserwowanego $\mathrm{w}$ angielskim i hiszpańskim i czy utrzyma się asymetria pomiędzy używaniem a rozumieniem form fleksyjnych. Korzystając $z$ intermodalnego paradygmatu preferencji wzrokowej sprzężonego z okulografem przetestowały one dwie grupy dzieci (2-3 lat i 3-4 lat) oraz grupę dorosłych (średnia wieku 26 lat). W badaniu, uczestnicy po wcześniejszym usłyszeniu zdań mieli wybrać rysunki ilustrujące następujące znaczenie Sie fütter-t einen Hund.(sg) (Ona karmi psa) oraz Sie fütter-n einen Hund. (pl) (Oni karmią psa). W analizie suma trwania fiksacji została uśredniona. Starsze dzieci (3-4 lat) oraz dorośli wykazali podobną wrażliwość na formy fleksyjne. Ponadto grupa starszych dzieci poprawnie przetwarzała różnice fleksyjne wykazując pełniejsze rozumienie formy fleksyjnej trzeciej osoby liczby pojedynczej (w przeciwieństwie do V.E. Johnson/ J.G. de Villiers/ H.N. Seymour/ A. Perez-Leroux 2005). Asymetria w rozumieniu i używaniu form fleksyjnych zaobserwowana we wcześniejszych badaniach nie została odnotowana przez O. Brandt/ B. Höhle.

\section{Metoda}

\section{Pytania badawcze}

Obecne badanie ma charakter diagnostyczny, ponieważ chcemy przede wszystkim przekonać się, w jaki sposób najlepiej wykorzystać okulograf do badań nad przetwarzaniem morfosyntaktycznym. $\mathrm{W}$ tym celu poddajemy analizie przetwarzanie struktur morfosyntaktycznych przez nierodzimych, dorosłych, zaawansowanych użytkowników języka angielskiego; przetwarzanie morfosyntaktyczne jest niedostatecznie opracowane w literaturze biorąc pod uwagę badania typu online. Naszym zamiarem jest zbadanie, czy i dlaczego niektóre formy fleksyjne są bardziej niż inne podatne na niepoprawne użycie. Skupiamy się na czterech formach fleksyjnych, z których trzy (liczba mnoga, trzecia osoba liczby pojedynczej czasu teraźniejszego, czas przeszły) tworzone są przez afiksację, podczas gdy derywacja czwartej formy (dopełniacza saksońskiego) jest bardziej złożona. Dlatego też pytamy:

1. Czy wrażliwość na błędy fleksyjne uzależniona jest od stopnia złożoności form fleksyjnych? Czy trudniejsze do przetworzenia będą formy bardziej złożone? 
2. Czy błędy fleksyjne o rożnej złożoności będą generowały różne długości fiksacji (im prostsza forma tym szybsza identyfikacja błędu i krótsza fiksacja)?

3. Czy możliwa będzie do zaobserwowania różnica pomiędzy formami poprawnymi i błędnymi poszczególnych form fleksyjnych? Czy błędy są przetwarzane dłużej?

4. Czy okulograf jest właściwych narzędziem do zbadania przetwarzania morfosyntaktycznego i czy badanie okulograficzne może posłużyć, jako wskaźnik złożoności form fleksyjnych w języku angielskim?

\section{Uczestnicy}

W obecnym badaniu analizowane było przetwarzanie struktur morfosyntaktycznych przez 35 zawansowanych użytkowników języka angielskiego (średnia wieku 24 lata), dla których polski jest językiem rodzimym i których znajomość języka angielskiego kształtuje się na poziomie C1 według Europejskiego Systemu Opisu Kształcenia Językowego (ESOKJ). Dodatkowo językowa homogeniczność grupy została potwierdzona ujednoliconym testem Michigan English Language Assessment Battery (Michigan Language Proficiency Test - Grammar Component). W badaniu wzięły udział jedynie te osoby, które zdobyły minimum $85 \%$ na wyżej wymienionym teście gramatycznym.

\section{Bodźce}

Łącznie w eksperymencie zastosowano 100 bodźców (plus pięć zdań próbnych), z których 80 stanowiły zdania eksperymentalne ${ }^{1}$ a 20 zdania rozpraszające (fillers) również $\mathrm{w}$ formie zdań. Zdania eksperymentalne podzielone były na dwie kategorie: 1. 40 zdań poprawnych - 10 AGR (1), 10 PLU (1), 10 PAST (1), 10 POSS (1) oraz 2. 40 zdań błędnych -10 AGR (0), 10 PLU (0),10 PAST (0), 10 POSS (0). Ponadto zdania rozpraszające zawierały poprawne bądź błędne frazy przyimkowe. Przygotowane zostały dwa zestawy eksperymentalne, A i B. Porządek zdań w obydwu zestawach był losowy. W zdaniach eksperymentalnych wzięto pod uwagę:

\footnotetext{
1 Większość badań zajmujących się przetwarzaniem morfologicznym/fleksyjnym języka drugiego analizowała je na poziomie leksykalnym. M. Paradis (2004) zauważył, że poziom leksykalny jest niewłaściwy i niedostateczny żeby zrozumieć przetwarzanie fleksyjne ponieważ w normalnym używaniu języka słowa występują w kontekście zdaniowym gdzie składniowe, pragmatyczne jak i semantyczne aspekty wpływają na ich rozumienie i funkcje. Wyniki badania opartego na informacji leksykalnej nie mogą dostarczyć wiedzy na temat tego jak przetwarzamy język, kiedy używamy go w codziennej komunikacji; informują one jedynie, w jaki sposób pozyskujemy informacje z naszej długoterminowej pamięci. M. Paradis przeanalizował badania $\mathrm{z}$ wykorzystaniem metody neuroobrazowania przeprowadzone $\mathrm{w}$ grupach rodzimych i nierodzimych użytkowników angielskiego i zauważył różnice w aktywowaniu różnych obszarów mózgu między obydwoma grupami na poziomie składniowym (zdania), ale nie na poziomie leksykalnym (słowa). Jego zdaniem dzieje się tak, dlatego, że słowa pozbawione kontekstu są traktowane wyłącznie jako elementy leksykalne w całości pozyskiwane z pamięci.
} 
- częstotliwość występowania danego czasownika/rzeczownika w British National Corpus;

- częstotliwość występowania drugiego rzeczownika we frazie rzeczownikowej tworzącej formę dzierżawczą;

- pozycję krytycznej formy fleksyjnej w zdaniu eksperymentalnym (formy fleksyjne AGR, PAST zajmowały 4-5 pozycję w zdaniu, natomiast formy PLU i POSS 1-3 pozycję w zdaniu);

- liczbę sylab w czasowniku/ rzeczowniku (1-2);

- liczbę wyrazów w zdaniu (8-9 wyrazów);

- pozycję zdania na ekranie (niezmienna, centralna we wszystkich zdaniach);

- rodzaj i wielkość czcionki (Times New Roman, rozmiar czcionki 72).

Bodźce i zdania rozpraszające były usytuowane centralnie na 14 calowym ekranie i prezentowane zdanie po zdaniu czarnymi literami na białym tle.

\section{Przebieg badania}

W części okulograficznej uczestnicy testowani byli indywidualnie, a ich zadaniem było uważne przeczytanie zdań zawierających poprawne jak i błędne formy fleksyjne (rzeczownikowe oraz czasownikowe). Przed przystąpieniem do eksperymentu uczestnicy poddani zostali kalibracji. W tym celu wymagane było, aby uczestnicy mieli możliwość przyzwyczajenia się do natężenia światła w pokoju badań, co zapewniło wiarygodność kalibracji. Odległość uczestników od monitora uwarunkowana była potencjalną wadą wzroku oraz jakością kalibracji ( $>1.0$ ) i nie przekraczała $40 \mathrm{~cm}$. W badaniu wykorzystano okulograf SMI RED o próbkowaniu $250 \mathrm{~Hz}$. Badanie zostało przeprowadzone przy stałym natężeniu oświetlenia. W analizie uwzględniono następujące zmienne: $d$ well time (DT, suma trwania wszystkich fiksacji wraz z sakadami dla danego obszaru zainteresowania), fixation count ( $\mathrm{FC}$, liczba fiksacji), fixation time (FT, czas trwania fiksacji) oraz average fixation (AF, średnia fiksacji). Skupiamy się na fiksacjach, czyli relatywnie stałych pozycjach gałki ocznej, w trakcie których następują niewielkie drgania ponieważ, w przeciwieństwie do sakad (intensywnych ruchów gałki ocznej charakteryzujących się bardzo szybkim przemieszczaniem punktu koncentracji wzroku z jednego miejsca na inne), w trakcie trwania fiksacji zachodzi proces poznawczy. Innymi słowy, bodźce docierające do mózgu gdzie są poddawane analizie i świadomie przetwarzane.

\section{Procedura}

W badaniu wzięli udział ci z uczestników, którzy zostali pomyślnie skalibrowani. Po przeczytaniu powitania uczestnicy przeszli do części eksperymentalnej. 


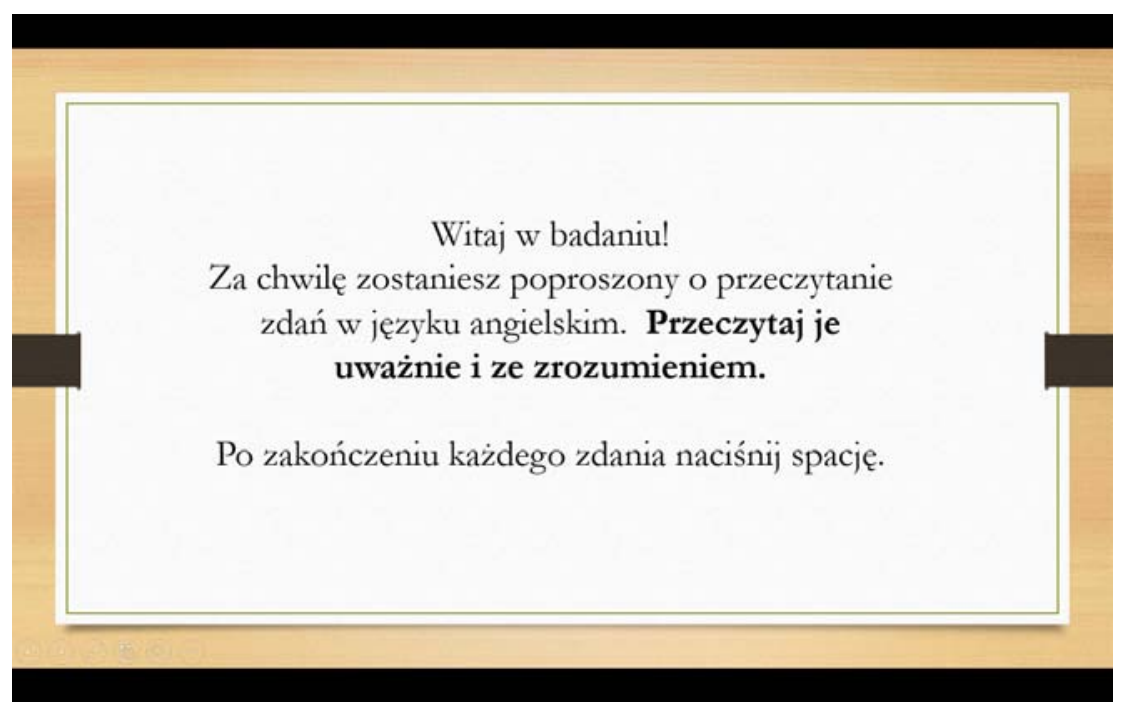

Pięć pierwszych zdań próbnych nie weszło do analizy; stanowiły one swego rodzaju „rozgrzewkę" i pozwoliły uczestnikom przyzwyczaić się do formy badania. Poniższy przykład przedstawia zdanie poprawne z użyciem związku zgody (AGR1).

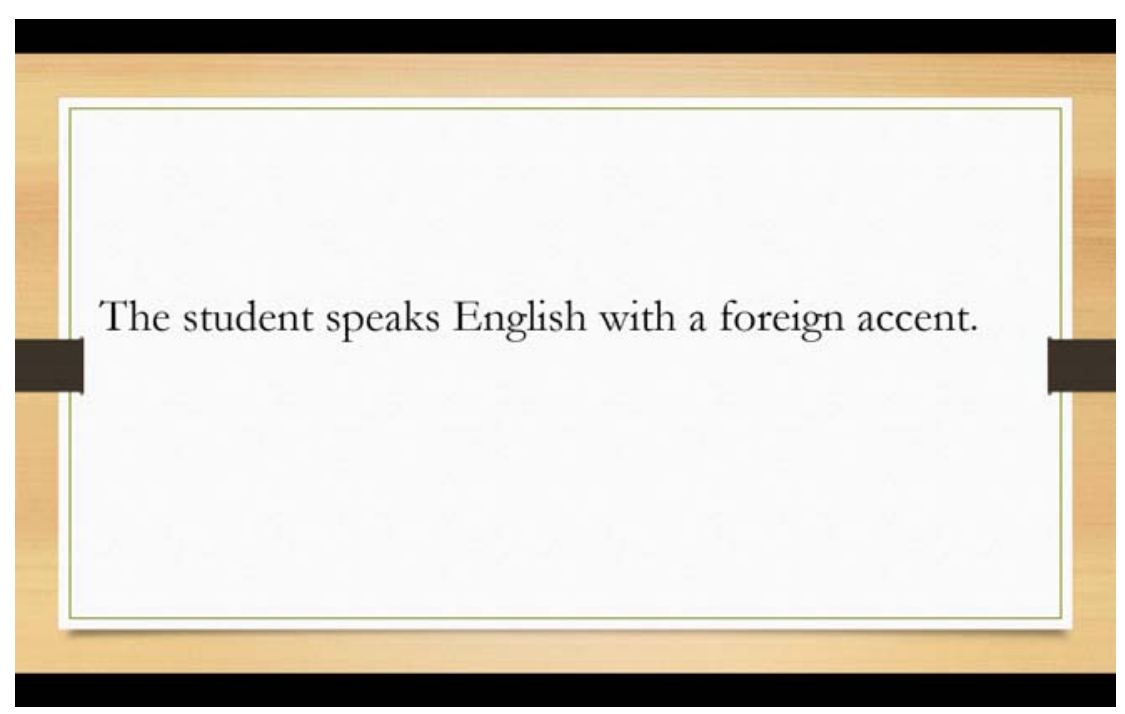

Rysunek 1. Przykładowy bodziec typu AGR (1).

Następny przykład przedstawia zdanie błędne z użyciem związku zgody (AGR 0), w którym czasownik (eat) nie ma końcówki fleksyjnej -s. 


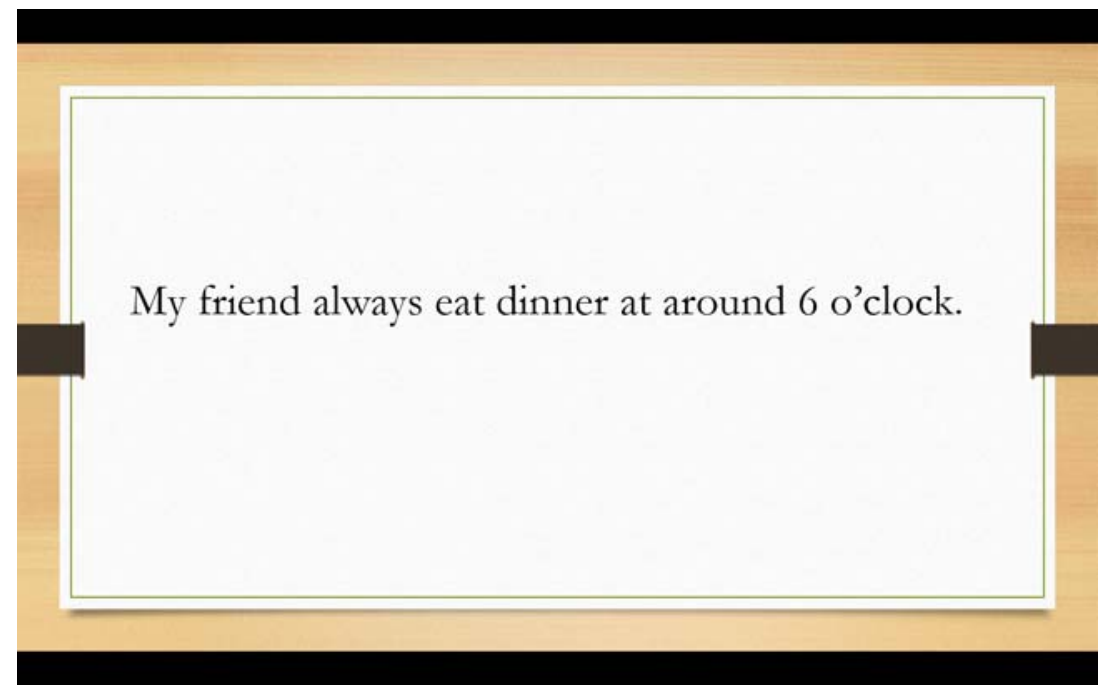

Rysunek 2. Przykładowy bodziec typu AGR (0).

Przykład trzeci przedstawia zdania błędne z użyciem liczby mnogiej (PLU 0). Zdania tego typu były jedynymi, w których bodziec znajdował się na początku, a nie w środku zdania.

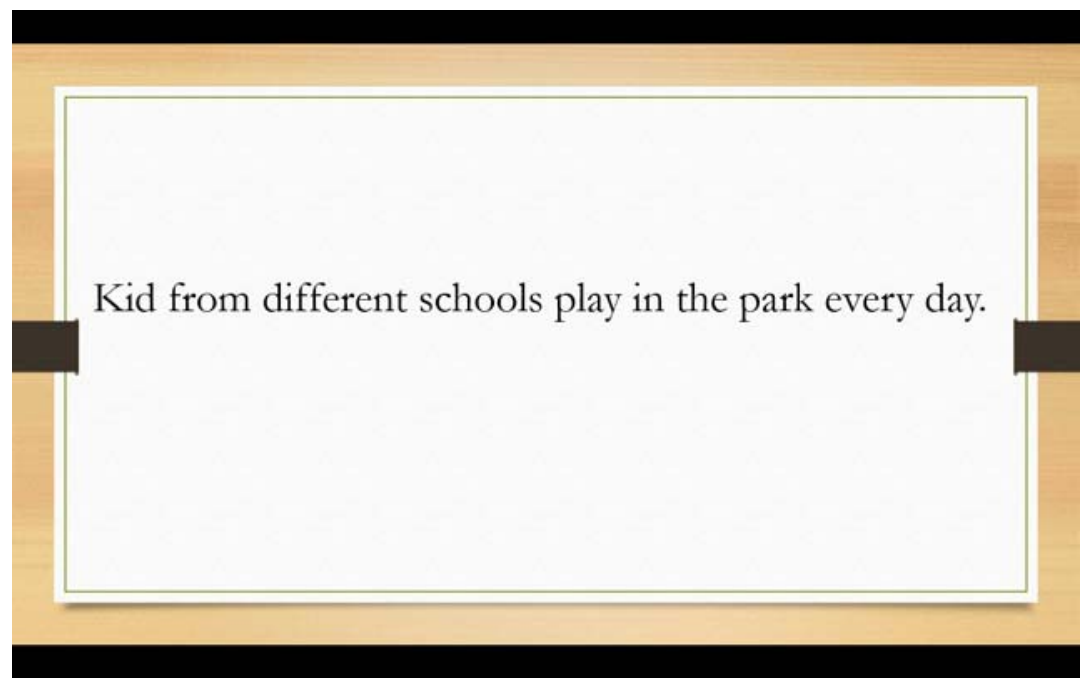

Rysunek 3. Przykładowy bodziec typu PLU (0).

\section{Wyniki badania}

Tabela 1 przedstawia cztery zmienne, które zostały przeanalizowane w czterech kategoriach zależności (par) wyszczególnionych kolorami w tabeli i wyjaśnionych w legendzie. 


\section{Tabela 1. Kategorie zależności między zmiennymi}

Kolor niebieski - różnica pomiędzy średnimi form poprawnych i błędnych poszczególnej zmiennej

Kolor czarny - różnica pomiędzy kumulatywną średnią form poprawnych i kumulatywną średnią form błędnych wszystkich zmiennych

Kolor czerwony -- różnica pomiędzy średnimi poprawnych form poszczególnych zmiennych

Kolor zielony - różnica pomiędzy średnimi błędnych form poszczególnych zmiennych

${ }^{1}$ Total (1) - suma wszystkich form poprawnych $\rightarrow$ AGR (1) + PAST (1) + PLU (1) + POSS (1)

${ }^{2}$ Total (0) - suma wszystkich form błędnych $\rightarrow$ AGR (0) + PAST (0) + PLU (0) + POSS (0)

\begin{tabular}{|c|c|c|c|}
\hline ie $[1$ & at & ns] & $\begin{array}{l}\text { Average } \\
\text { [ms] }\end{array}$ \\
\hline GR (1) vs. AGR & $\begin{array}{l}\text { AGR (1) vs. AGR } \\
(0)\end{array}$ & $\begin{array}{l}\text { AGR (1) vs. AGR } \\
(0)\end{array}$ & $\begin{array}{l}\text { AGR (1) vs. AGR } \\
(0)\end{array}$ \\
\hline AST(1) & PAST(1) & PAST(1) & PASTC1) \\
\hline$A S T(0)$ & PAST(0) & PAST(0) & $\Gamma(0)$ \\
\hline $\begin{array}{l}\text { PLU (1) vs. PLU } \\
(0)\end{array}$ & $\begin{array}{l}\text { PLU (1) vs. PLU } \\
(0)\end{array}$ & $\begin{array}{l}\text { PLU (1) vs. PLU } \\
(0)\end{array}$ & \\
\hline $\begin{array}{l}\text { POSS (1) vs. POSS } \\
(0)\end{array}$ & $\begin{array}{l}\text { POSS (1) vs. POSS } \\
\text { (0) }\end{array}$ & $\begin{array}{l}\text { POSS (1) v } \\
(0)\end{array}$ & $\begin{array}{l}\text { POSS (1) vs. } \\
(0)\end{array}$ \\
\hline $\begin{array}{l}\text { Total }(1)^{4} \text { vs. Total } \\
(0)^{2} \\
\text { AGR (1) vs. PAS T } \\
(1)\end{array}$ & $\begin{array}{l}\text { Total (1) vs. Total } \\
\text { (0) } \\
\text { AGR (1) vs. PAST } \\
\text { (1) }\end{array}$ & $\begin{array}{l}\text { Total (1) vs. Total } \\
(0) \\
\text { AGR (1) vs. PAST } \\
(1)\end{array}$ & $\begin{array}{l}\text { Total (1) vs. Total } \\
(0) \\
\text { AGR (1) vs. PAS T } \\
\text { (1) }\end{array}$ \\
\hline AGR (1) vs. PLU & AGR (1) vs. PLU & $\begin{array}{l}\text { AGR (1) vs. PLU } \\
\text { (1) }\end{array}$ & AGR(1) vs. PLU (1) \\
\hline $\begin{array}{l}\text { AGR (1) vs. POSS } \\
\text { (1) }\end{array}$ & 1) vs. POSS & $\begin{array}{l}\text { AGR } \\
\text { (1) }\end{array}$ & $\begin{array}{l}\text { AGR (1) vs. POSS } \\
\text { (1) }\end{array}$ \\
\hline $\begin{array}{l}\text { PAST (1) vs. PLU } \\
\text { (1) }\end{array}$ & $\begin{array}{l}\text { PAST (1) vs. PLU } \\
\text { (1) }\end{array}$ & $\begin{array}{l}\text { PAST (1) vs. PLU } \\
\text { (1) } \\
\end{array}$ & $\begin{array}{l}\text { PAST (1) vs. PLU } \\
\text { (1) }\end{array}$ \\
\hline PAST (1) vs. POSS & $\begin{array}{l}\text { PAST (1) vs. POSS } \\
\text { (1) }\end{array}$ & PAST (1) vs. POSS & $\begin{array}{l}\text { PAST (1) vs. POSS } \\
\text { (1) }\end{array}$ \\
\hline $\begin{array}{l}\text { PLU (1) vs. POSS } \\
\text { (1) }\end{array}$ & $\begin{array}{l}\text { PLU (1) vs. } \\
\text { (1) }\end{array}$ & $\begin{array}{l}\text { PLU (1) v } \\
\text { (1) }\end{array}$ & $\begin{array}{l}\text { PLU (1) vs. } \\
\text { (1) }\end{array}$ \\
\hline $\begin{array}{l}\text { AGR }(0) \text { vs. PAS T } \\
(0)\end{array}$ & $\begin{array}{l}\text { AGR (0) vs. PAST } \\
(0)\end{array}$ & $\begin{array}{l}\text { AGR (0) vs. PAST } \\
(0)\end{array}$ & $\begin{array}{l}\text { AGR (0) vs. PAST } \\
(0)\end{array}$ \\
\hline $\begin{array}{l}\text { AGR (0) vs. PLU } \\
(0)\end{array}$ & $\begin{array}{l}\text { AGR (0) vs. PLU } \\
(0)\end{array}$ & $\begin{array}{l}\text { AGR (0) vs. PLU } \\
(0)\end{array}$ & AGR (0) vs. $\mathrm{P}$ \\
\hline $\begin{array}{l}\text { AGR (0) vs. POSS } \\
(0)\end{array}$ & $\begin{array}{l}\text { AGR (0) vs. POSS } \\
(0)\end{array}$ & $\begin{array}{l}\text { AGR }(0) \text { vs. POSS } \\
(0)\end{array}$ & $\begin{array}{l}\text { AGR (0) vs. POSS } \\
(0)\end{array}$ \\
\hline $\begin{array}{l}\text { PAST (0) vs. PLU } \\
(0)\end{array}$ & $\begin{array}{l}\text { PAST (0) vs. PLU } \\
(0)\end{array}$ & $\begin{array}{l}\text { PAST (0) vs. PLU } \\
(0)\end{array}$ & $\begin{array}{l}\text { PAST (0) vs. PLU } \\
(0)\end{array}$ \\
\hline $\begin{array}{l}\text { PAST (0) vs. POSS } \\
(0)\end{array}$ & $\begin{array}{l}\text { PAST (0) vs. POSS } \\
(0)\end{array}$ & $\begin{array}{l}\text { PAST (0) v } \\
(0)\end{array}$ & $\begin{array}{l}\text { PAST (0) vs. Pr } \\
(0)\end{array}$ \\
\hline PLU (0) vs. POSS & PLU (0) vs. POSS & PLU (0) vs. POSS & PLU (0) vs. POSS \\
\hline
\end{tabular}

Wyniki analizy zostaną przedstawione w odniesieniu do poszczególnych pytań badawczych. 


\subsection{Pytanie Badawcze 1}

Czy błędy fleksyjne o rożnej złożoności będa generowaty różne długości fiksacji (im prostsza forma tym szybsza identyfikacja btędu i krótsza fiksacja)?

Tabela 2 przedstawia średnie dla średniej wartości skupienia wzroku i średnie dla czasu trwania fiksacji oraz istotność statystyczną dla poprawnych form prostszych elementów fleksyjnych (AGR, PAST, PLU) w porównaniu z poprawnymi formami bardziej złożonego elementu fleksyjnego POSS.

\begin{tabular}{|l|llll|}
\hline & AGR1AF (Mean 164,6400) & vs. POSS1AF & (Mean \\
AGR vs. & 219,5491) $\mathrm{p}=.0034$ & & \\
POSS & AGR1FT (Mean 451,9186) & vs. POSS1FT & (Mean \\
& $710,0423) \mathrm{p}=.0001$ & & \\
\hline & PAST1AF (Mean 172,5186) & vs. POSS1AF & (Mean \\
PAST vs. & $219,5491) \mathrm{p}=.0158$ & & \\
POSS & PAST1FT (Mean 545,3709) & vs. POSS1FT & (Mean \\
& $710,0423) \mathrm{p}=.0042$ & & \\
\hline & PLU1AF (Mean 159,4789) & vs. POSS1AF & (Mean \\
PLU vs. & $219,5491) \mathrm{p}=.0016$ & & \\
POSS & PLU1FT (Mean 512,4426) & vs. POSS1FT & (Mean \\
& $710,0423) \mathrm{p}=.0003$ & & \\
\hline
\end{tabular}

Tabela 2 Formy poprawne (a Paired samples t-test).

Zaobserwowaliśmy istotność statystyczną pomiędzy poprawnymi formami prostszych elementów fleksyjnych (AGR, PAST, PLU) i poprawnymi formami złożonego elementu fleksyjnego POSS. Forma POSS generowała wyższe wartości, czyli była przetwarzana dłużej. W szczególności:

\section{AGR vs. POSS}

Test t dla prób zależnych do oceny istotności różnicy średnich wykazał statystycznie znaczącą różnicę pomiędzy związkiem zgody (AGR) i formą dzierżawczą (POSS) dla średniej wartości skupienia wzroku $(\mathrm{p}=.0034)$ i czasu trwania fiksacji $(\mathrm{p}=$ .0001).

\section{PAST vs. POSS}

Test $\mathrm{t}$ dla prób zależnych do oceny istotności różnicy średnich wykazał, że różnica pomiędzy czasem przeszłym (PAST) a formą dzierżawczą (POSS) jest statystycznie istotna dla średniej wartości skupienia wzroku $(\mathrm{p}=.0158) \mathrm{i}$ czasu trwania fiksacji $(\mathrm{p}$ $=.0042$ ).

\section{PLU vs. POSS}

Test $t$ dla prób zależnych do oceny istotności różnicy średnich wykazał statystycznie znaczącą różnicę pomiędzy formą liczby mnogiej PLU a formą dzierżawczą (POSS) dla średniej wartości skupienia wzroku $(\mathrm{p}=.0016)$ i czasu trwania fiksacji $(\mathrm{p}=$ $.0003)$.

Tabela 3 przedstawia średnie dla średniej wartości skupienia wzroku i średnie dla czasu trwania fiksacji oraz istotność statystyczną dla błędnych form prostszych 
elementów fleksyjnych (AGR, PAST, PLU) w porównaniu z błędnymi formami bardziej złożonego elementu fleksyjnego POSS.

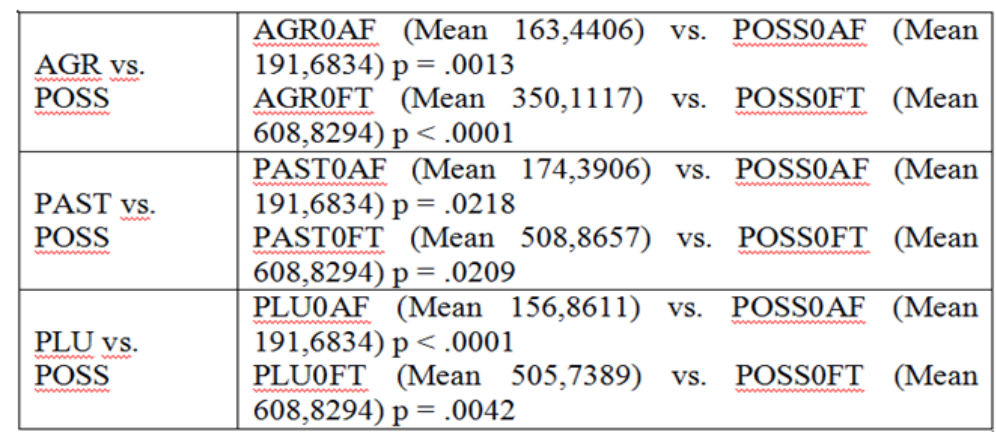

Tabela 3 Formy btędne ( ${ }^{a}$ Paired samples t-test).

Zaobserwowaliśmy istotność statystyczną pomiędzy błędnym formami prostszych elementów fleksyjnych (AGR, PAST, PLU) oraz błędnymi formami złożonego elementu fleksyjnego POSS. Podobnie jak w przypadku zdań poprawnych, forma POSS była przetwarzana najdłużej spośród czterech form fleksyjnych. W szczególności:

\section{AGR vs. POSS}

Test $t$ dla prób zależnych do oceny istotności różnicy średnich wykazał statystycznie znaczącą różnicę pomiędzy związkiem zgody (AGR) i formą dzierżawczą (POSS) dla średniej wartości skupienia wzroku $(\mathrm{p}=.0013)$ i czasu trwania fiksacji $(\mathrm{p}<$ $.0001)$.

\section{PAST vs. POSS}

Test $t$ dla prób zależnych do oceny istotności różnicy średnich wykazał, że różnica pomiędzy czasem przeszłym (PAST) a formą dzierżawczą (POSS) jest statystycznie istotna dla średniej wartości skupienia wzroku $(\mathrm{p}=.0218)$ i czasu trwania fiksacji $(\mathrm{p}$ $=.0209)$.

\section{PLU vs. POSS}

Test $t$ dla prób zależnych do oceny istotności różnicy średnich wykazał statystycznie znaczącą różnicę pomiędzy formą liczby mnogiej PLU a formą dzierżawczą (POSS) dla średniej wartości skupienia wzroku $(\mathrm{p}<.0001)$ i czasu trwania fiksacji $(\mathrm{p}=.0042)$.

Analiza zależności zmiennych pozwoliła również na następującą obserwację. Mianowicie zaobserwowaliśmy również istotność statystyczną w grupie błędnych form prostszych elementów fleksyjnych, czyli czasu przeszłego (PAST) i liczny mnogiej (PLU) oraz czasu przeszłego (PAST) i związku zgody (AGR). W szczególności test $t$ dla prób zależnych do oceny istotności różnicy średnich wykazał, że różnica pomiędzy: 1. czasem przeszłym (PAST) a liczbą mnogą (PLU) jest statycznie istotna dla średniej wartości skupienia wzroku $(\mathrm{p}=.0453) ; 2$. czasem przeszłym (PAST) a związkiem zgody (AGR) jest statycznie istotna dla czasu trwania fiksacji $(\mathrm{p}=.0007)$. 
Tabela 4 przestawia średnie dla średniej wartości skupienia wzroku i średnie dla czasu trwania fiksacji oraz istotność statystyczną dla błędnych form prostszych elementów fleksyjnych (AGR, PLU) w porównaniu z błędnymi formami innego prostego elementu fleksyjnego PAST.

\begin{tabular}{|l|lll|}
\hline PAST vs. & PAST0AF (Mean 174,3906) & vs. PLU0AF (Mean \\
PLU & $156,8611) \mathrm{p}=.0453$ & & \\
\hline PAST vs. & PAST0FT (Mean 508,8657) & vs.AGR0FT (Mean \\
AGR & $350,1117) \mathrm{p}=.0007$ & & \\
\hline
\end{tabular}

Tabela 4 ( ${ }^{a}$ Paired samples $t$-test).

Biorąc pod uwagę dotychczasową analizę, wydaje się, że nie liczba, ale średnia fiksacji oraz czas fiksacji są istotnymi wskaźnikami w badaniu przetwarzania morfosyntaktycznego.

\subsection{Pytanie Badawcze 2}

Czy możliwa będzie do zaobserwowania różnica pomiędzy formami poprawnymi $i$ blędnymi?

Tabela 5 zawiera średnią kumulatywną wszystkich form poprawnych (1) zestawioną ze średnią kumulatywną wszystkich form błędnych (0).

\begin{tabular}{|l|}
\hline Dwell time Total (1) (Mean 2297,9106) vs. Total (0) (Mean \\
$1994,7446) \mathrm{p}=.0004$ \\
\hline Fixation Count Total (1) (Mean 11,1871) vs. Total (0) (Mean \\
$9,5203) \mathrm{p}=.0005$ \\
\hline Fixation Time Total (1) (Mean 2219,7743) vs. Total (0) (Mean \\
$1973,5457) \mathrm{p}=.0025$
\end{tabular}

Tabela 5 Total $(1)^{1}$ vs. Total $(0)^{2}\left({ }^{a}\right.$ Paired samples t-test).

Zaobserwowaliśmy statystycznie istotną różnicę pomiędzy średnią kumulatywną wszystkich zdań zawierających formy poprawne oraz średnią kumulatywną wszystkich zdań zawierających formy błędne. W szczególności, test $t$ dla prób zależnych do oceny istotności różnicy średnich wykazał statystycznie znaczącą różnicę pomiędzy kumulatywną średnią form poprawnych i kumulatywną średnią form niepoprawnych w trzech kategoriach: 1. dwell time, czyli sumy długości wszystkich fiksacji wraz z sakadami dla danego obszaru zainteresowania $(p=.0004), 2$. liczby fiksacji $(p=.0005)$ oraz 3 . czasu fiksacji $(p=.0025)$. Poniżej wyniki kumulatywne przedstawione zostały w formie grafów. 


\section{Graf 1}

Kumulatywna średnia form poprawnych i kumulatywna średnia form niepoprawnych dla dwell time

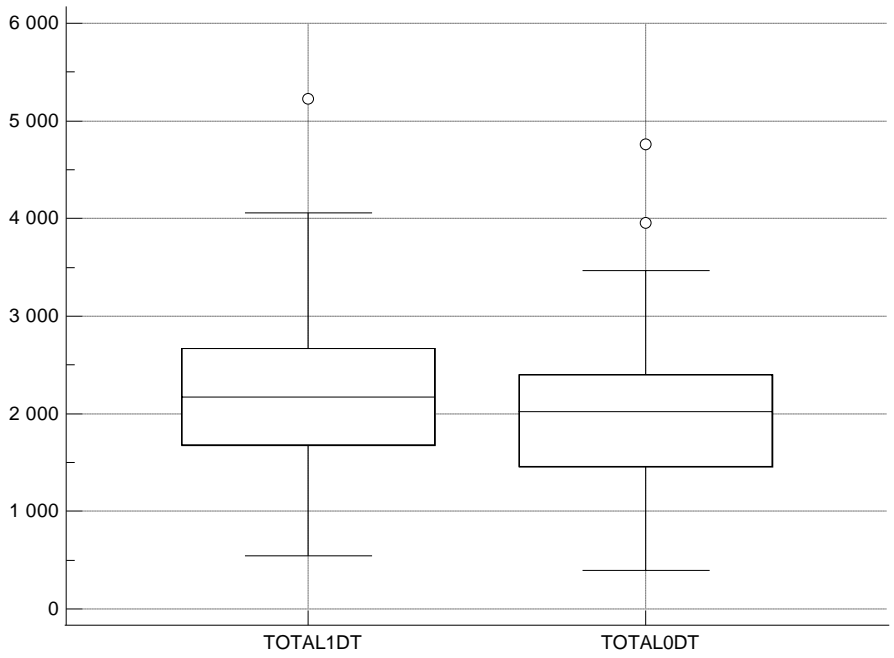

Graf 2

Kumulatywna średnia form poprawnych i kumulatywna średnia form niepoprawnych dla liczby fiksacji

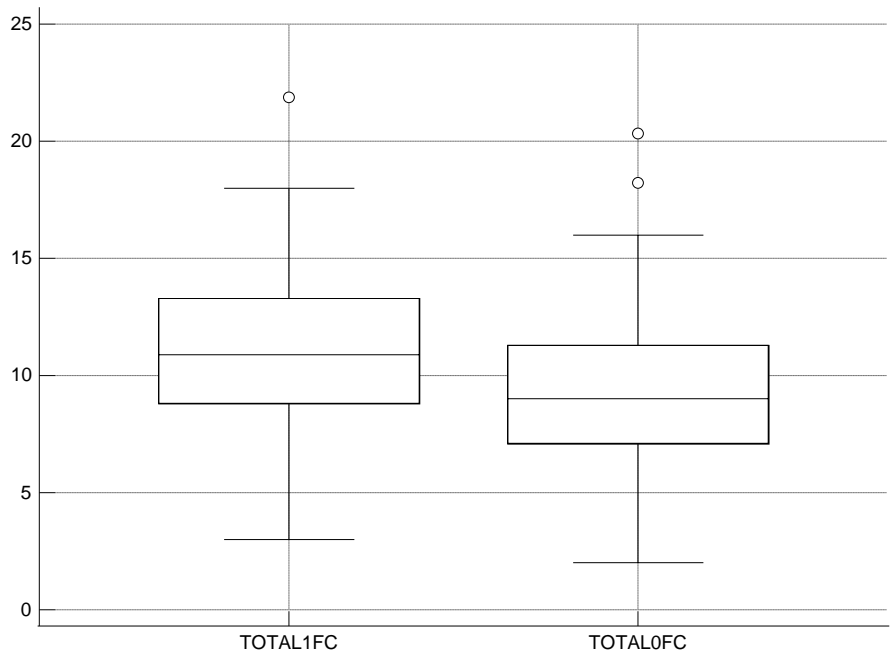


Graf 3

Kumulatywna średnia form poprawnych i kumulatywna średnia form niepoprawnych dla czasu fiksacji

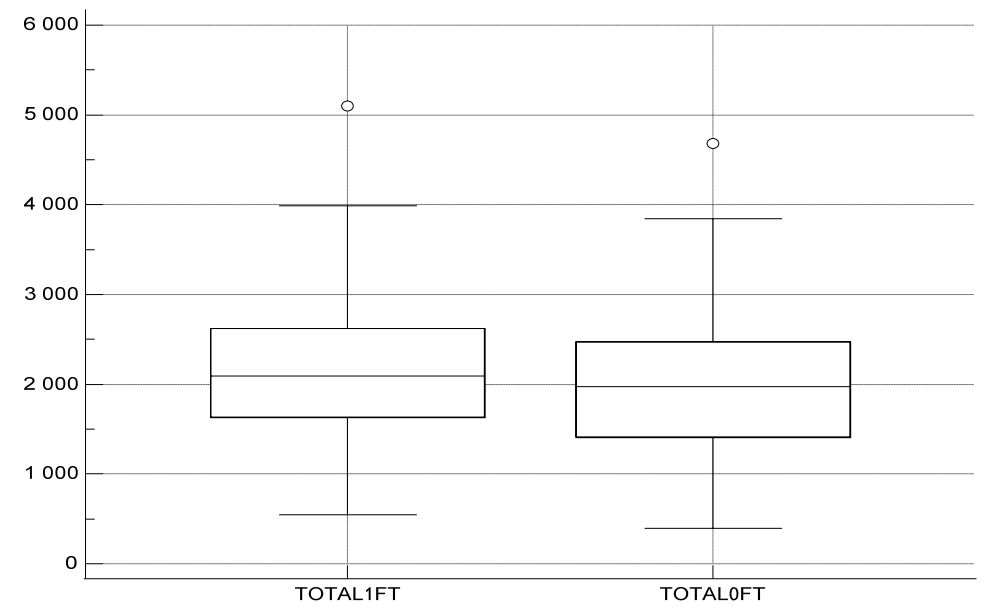

Formy poprawne mają wysokie wartości średnich. Jak zaobserwowaliśmy, różnica między kumulatywnymi średnimi form poprawnych i kumulatywnymi średnimi form błędnych wykazuje istotność statystyczną. Jednakże kierunek tej zależności jest przeciwny od oczekiwanego. Spodziewaliśmy się, że błędy będą generowały zarówno więcej fiksacji jak i dłuższe fiksacje. Analiza dowodzi jednak, że formy poprawne są długo przetwarzane przez uczestników.

Tabela 6 przedstawia średnie form poprawnych (1) w zestawieniu ze średnimi form błędnych (0) poszczególnych zmiennych.

\begin{tabular}{|c|c|}
\hline POSS & $\begin{array}{l}\text { POSS1FT (Mean 710,0423) vs. POSS0FT (Mean } \\
608,8294) p=.0535 \\
\text { POSS1FC (Mean 3,5363) vs. POSS0FC (Mean } \\
2,9469) p=.1304\end{array}$ \\
\hline AGR & $\begin{array}{l}\text { AGR1FT (Mean 451,9186) vs. AGR0FT (Mean } \\
350,1117) p=.0033 \\
\text { AGR1FC (Mean 2,2791) vs. AGR0FC (Mean 1,7394) } \\
\mathrm{p}=.0011\end{array}$ \\
\hline PAST & $\begin{array}{l}\text { PAST1FT (Mean 545,3709) vs. PAST0FT (Mean } \\
508,8657) \mathrm{p}=.4990 \\
\text { PAST1FC (Mean 2,7366) } \\
2,3497) \mathrm{p}=.0410\end{array}$ \\
\hline PLU & $\begin{array}{l}\text { PLU1FT (Mean 512,4426) vs. PLU0FT (Mean } \\
505,7389) \mathrm{p}=.7949 \\
\text { PLU1FC (Mean 2,6349) vs. PLU0FC (Mean 2,4863) } \\
\mathrm{p}=.2551\end{array}$ \\
\hline
\end{tabular}

Tabela 6 Średnie czastkowe form poprawnych i btędnych (1) vs. (0) ( ${ }^{a}$ Paired samples $t$-test). 
Podobnie jak w przypadku średnich kumulatywnych średnie poszczególnych form poprawnych wszystkich zmiennych mają wyższe wartości niż średnie poszczególnych form błędnych. W obydwu typach średnich obserwujemy tę samą zależność: Mean (1) > Mean (0).

\subsection{Pytanie Badawcze 3}

Czy badanie okulograficzne może posłużyć jako wskaźnik złożoności form fleksyjnych w języku angielskim?

Wyniki powyższych analiz dowodzą, że badanie okulograficzne jest nie tylko właściwym instrumentem do badania przetwarzania morfosyntaktycznego, ale również sugerują kierunek przyszłych badań z wykorzystaniem okulografu. Zagadnienie to zostanie szerzej omówione $\mathrm{w}$ dyskusji.

\section{Dyskusja}

W naszym badaniu koncentrowaliśmy się na morfosyntaktycznej analizie czterech form fleksyjnych: dopełniacza dzierżawczego (POSS), liczby mnogiej (PLU), związku zgody między podmiotem i orzeczeniem (AGR) oraz czasu przeszłego (PAST). Celem eksperymentu było zbadanie wrażliwości zaawansowanych użytkowników języka angielskiego na poprawne formy fleksyjne oraz na błędy fleksyjne charakteryzujące się rożnym stopniem złożoności. Do osiągnięcia tego celu wykorzystaliśmy okulograf.

\subsection{Forma dzierżawcza (POSS)}

Spośród przeanalizowanych form fleksyjnych na uwagę przede wszystkim zasługuje forma dzierżawcza (POSS), która generowała najwyższe wartości, czyli była przetwarzana najdłużej. Powody tego stanu rzeczy mogą być przy najmniej trzy: 1. proces derywacyjny POSS; 2 . jej natura typologiczna; 3 . jej status morfosyntaktyczny Odnosząc się do procesu derywacyjnego formy dzierżawczej należy zauważyć, że jest on przede wszystkim złożony (zob. M. den Dikken 1998, 2000). Formułujemy tezę, że kompleksowość formy dzierżawczej (POSS) wydaje się przyczyniać nie tylko do niepoprawnego użycia tej form, jak potwierdzają wcześniejsze badania (zob. H.C. Dulay/ M.K. Burt 1974, N. Bailey/ C. Madden/ S.D. Krashen 1974, D.E. Larsen-Freeman 1976, H. Zobl/ J. Liceras 1994, R.W. Andersen 1978, T. Pica 1983, B.J. Mace-Matluck 1979, Y. Nuibe 1986, Z.P. Luk/ Y. Shirai 2009), ale również do większego zaangażowana kognitywnego zaobserwowanego w obecnym eksperymencie okulograficznym. Zwłaszcza inwersja, czyli mechanizm syntaktyczny będący częścią składową derywacji tej formy fleksyjnej może sprawiać, że przetwarzanie i używanie POSS są trudniejsze niż stosowanie form, które nie wymagają inwersji (np. AGR, PLU, POSS). Forma dzierżawcza (np. John's mother) nie może być rozumiana linearnie, żeby ją zrozumieć trzeba odnieść się do pewnej zależności między rzeczownikami tworzącymi ją (possessor versus possessum). Zależność ta jest dowodem istnienia struktury morfoskładniowej. A tam gdzie jest struktura jest i 
hierarchia, za którą stoi większe wyzwanie związanie ze zrozumieniem relacji tworzących ją.

Ponadto mając na uwadze naturę typologiczną POSS, zauważamy za J.H. Greenberg'iem (1963), że konstrukcja dopełniacza w języku angielskim jest nietypowa w porównaniu do np. francuskiego (le chien de mon ami ,pies mojego przyjaciela”), rosyjskiego (sobaka mojego[GEN] druga[GEN] ,pies mojego przyjaciela”) czy włoskiego (il cane di mia madre ,pies mojej matki”) i być może z tego powodu trudniejsza, ponieważ jest ona reprezentowana nie tylko przez konstrukcje, w których possessum występuje przed possessor (np. the leg of the table), ale również przez frazy, w których ten porządek jest odwrotny (np. my friend's dog). Odnośnie statusu morfosyntaktycznego formy dzierżawczej należy stwierdzić, że w angielskim nie jest ona przypadkiem gramatycznym, ale elementem podobnym określnikowi (determiner), który bierze swój początek, jako nadrzędny element syntaktyczny frazy dzierżawczej tak jak ma to miejsce w przypadku przymiotników dzierżawczych (np. my, his, our) (zob. R. Cirillo 2016). Wszystko to odróżnia formę dzierżawczą od pozostałych elementów systemu fleksyjnego języka angielskiego i sprawia, że przetwarzanie i w konsekwencji używanie tej formy wymaga większego zaangażowania kognitywnego. Oko, a za nim i mózg, nie mogą tego zignorować. W końcu zrozumienie przetwarzania formy dzierżawczej w języku angielskim jest ważne $\mathrm{z}$ jeszcze innego powodu. Mianowicie poznanie tej konstrukcji morfosyntaktycznej może przyczynić się do pełniejszego zrozumienia innych struktur syntaktycznych, w których procesie derywacyjnym, czyli przejściu od struktury głębokiej do struktury powierzchniowej, występuje inwersja (np. pytania, strona bierna, mowa zależna).

\subsection{Czas przeszly (PAST)}

Następna interesująca obserwacja dotyczy zdań z błędnym użyciem regularnego czasu przeszłego, który w obecnym badaniu generował wyższe wartości w porównaniu ze zdaniami zawierającymi błędne formy liczby mnogiej i związku zgody. Innymi słowy, błędne użycie czasu przeszłego było przetwarzane dłużej niż błędne formy pozostałych dwóch form fleksyjnych tworzonych przez afiksację. Forma fleksyjna regularnego czasu przeszłego w języku angielskim jest ortograficznie reprezentowana przez jeden tylko morfem, -ed, który to fakt nie powinno stanowić trudności dla osób stosujących tę formę. Jest jednak inaczej. Trudności z implementacją regularnego czasu przeszłego zaobserwowano w zaburzeniach rozwojowych u dzieci anglojęzycznych ze specyficznym zaburzeniem językowym oraz w zaburzeniach nabytych u dorosłych anglojęzycznych pacjentów cierpiących na afazję Broki (zob. D.V.M. Bishop 2013). Problem poprawnego użycia czasu przeszłego jest nieobcy dzieciom i dorosłym uczącym się angielskiego jako języka drugiego/obcego (zob. Z.P. Luk/ Y. Shirai 2009). Być może fleksja angielska, pomimo że szczątkowa i jednolita paradygmatycznie wymaga dużego zaangażowania kognitywnego. Być może fleksja, chociaż stanowi mały element graficzny, jest jednak obciążeniem dla parsera, ponieważ wymaga uwagi jak i zrozumienia relacji pomiędzy poszczególnymi komponentami zdania. 
Jakich mechanizmów wymaga poprawne użycie regularnego czasu przeszłego? Różne sugestie pojawiają się jako możliwe odpowiedzi na to pytanie. Niewątpliwie mechanizm morfologiczny, który motywuje afiksację czasowników regularnych, stoi za poprawnym stosowaniem regularnej zasady czasu przeszłego (zob. S. Pinker 1999). Inną propozycją jest mechanizm syntaktyczny. Według teorii zasad i parametrów, czas przeszły podlega różnym procesom między innymi ustaleniu relacji z pozycją spójnika podrzędnego określanego również jako zaimek pytajny czy partykuła pytajna (complementizer) (zob. M. Enç 1987, J. Guéron/ T. Hoekstra 1995). Z kolei W. O’Grady (2006) upatruje źródła trudności jakich może przysparzać czas przeszły w jego związku z aspektem, czyli kategorią gramatyczną odnoszącą się do wewnętrznej struktury czasowej zdarzenia. ${ }^{2}$

Co wiemy na temat przetwarzania regularnej fleksji języka angielskiego, np. PAST? Niewiele jest badań nad przetwarzaniem regularnej fleksji w czasie rzeczywistym (zob. C. Pliatsikas/ T. Marinis 2013). Jednym z tych nielicznych jest eksperyment przeprowadzony przez R. Silva'ę/ H. Clahsen'a (2008), którzy zastosowali zamaskowaną technikę torowania. $\mathrm{W}$ badaniu udział wzięli zaawansowani uczniowie języka angielskiego reprezentujący różne języki ojczyste (np. chiński, japoński, niemiecki) i uczący się języka angielskiego średnio 11 lat w kontekście nauczania formalnego. W przeciwieństwie do uczestników eksperymentu, grupa kontrolna (rodzimi użytkownicy angielskiego) ulegała efektowi torowania w parach morfologicznych (prayed-pray) w porównaniu z parami, w których brak było związku morfologicznego (bake-pray). Nie zaobserwowano efektu torowania dla morfologicznie powiązanych par w grupie nierodzimych uczestników. Wyniki te zdają się dowodzić, że pomimo tego, iż odmienione formy fleksyjne były nieświadomie przetwarzane przez nierodzimych uczestników badania, nie przetwarzali oni nieodmienionych form; co zostało zinterpretowane jako dowód na brak morfologicznego związku pomiędzy nimi. Innymi słowy, regularne formy czasu przeszłego są rozumiane

${ }^{2}$ Rozumienie czasu gramatycznego jest zależne od uprzedniego określenia aspektu. Oznaką tego jest fakt, że w językach, w których aspekt wyrażany jest morfologicznie, występuje on bliżej trzonu czasownika niż czas (zob. J. Foley/ R. an Valin 1984:210). Ponadto, w tych językach, które określają aspekt morfologicznie jest on przyswajany przez uczniów wcześniej niż czas gramatyczny lub równocześnie z czasem, ale nigdy po czasie (zob. R. Van Valin 1991:16). Stosowanie czasu przeszłego wymaga korzystania z zasobów pamięci proceduralnej czyli takiego rodzaju pamięci długotrwałej, do której mamy automatyczny dostęp; pamięć deklaratywna czyli pamięć świadoma, okazuje się w tym względzie niewystarczająca. Taka argumentacja zakłada istnienie dwóch fundamentalnie różnych rodzajów wiedzy lingwistycznej. $\mathrm{Z}$ jednej strony, istnieje wiedza oparta na faktach takich jak informacje dotyczące kategorii i możliwości połączeń elementów leksykalnych, która jest stosunkowo łatwa do opisania i przyswojenia. Z drugiej strony, mamy do czynienia ze znacznie mniej konkretnym rodzajem wiedzy, który nie składa się z faktów, ale procedur. Procedury te odpowiadają podświadomym operacjom systemu przetwarzania, który tworzy i interpretuje zdania w trakcie mówienia i który jest ostatecznie odpowiedzialny za morfologiczne i składniowe kontrasty tworzące "gramatykę". 
jako anatomicznie niepodzielne elementy leksykalne i nie są przetwarzane jako formy zawierające składowe, temat i sufiks. R. Silva/ H. Clahsen sugerują, że niemożność analizy form morfologicznie złożonych u nierodzimych użytkowników języka wynika $\mathrm{z}$ braku mentalnych reprezentacji powiązanych $\mathrm{z}$ formami fleksyjnymi $\mathrm{w}$ repertuarze składniowym uczniów. Obecność tego typu mentalnych reprezentacji umożliwiłaby morfologiczne przetwarzanie form fleksyjnych. Odnosząc to do obecnego badania, krótszy czas fiksacji form nieodmienionych (tutaj błędnych) w porównaniu z czasem fiksacji form odmienionych (tutaj poprawnych) oraz statystycznie znacząca różnica $w$ grupie błędnych form fleksyjnych tworzonych poprzez afiksację mogą również sugerować brak pełnej sprawności morfosyntaktycznej w przetwarzaniu błędów czy też brak spójności w świadomym przetwarzaniu tych form, w których nie wystąpiły końcówki fleksyjne.

Jednakże wyniki uzyskane przez R. Silva'ę/ H. Clahsen'a nie pokrywają z tymi, które uzyskał B. Kirkici (2005) w badaniu nad przetwarzaniem fleksji drugiego języka. B. Kirkici zastosował paradygmat decyzji leksykalnych do zbadania odmienionych czasowników regularnych i nieregularnych o dużej i małej częstotliwości używania w dwóch grupach Turków uczących się języka angielskiego: zaawansowanej i początkującej. Ważna dla obecnego badania jest obserwacja B. Kirkici'a dotycząca grupy zaawansowanej; jej członkowie, mianowicie, byli wolniejsi w rozpoznawaniu regularnych form $\mathrm{w}$ porównaniu $\mathrm{z}$ nieregularnymi, co miałoby dowodzić, że w rozpoznawaniu tego typu form bierze udział dodatkowy proces, dekompozycja. Ponadto B. Kirkici stwierdza, że regularny czas przeszły jest jedną z tych zasad, której stosowanie może być „zautomatyzowane” w przypadku zaawansowanych uczniów języka angielskiego. W obecnym badaniu również wzięli udział zaawansowani uczniowie języka angielskiego. Nie możemy jednak bezpośrednio porównać wyników obydwu badań ze względu na różnicę w zastosowanej metodzie oraz bodźcach. Podobnie jak u B. Kirkici'a, w obecnym badaniu zaobserwowaliśmy wolniejsze przetwarzanie materiału fleksyjnego. Tutaj jednak odnosiło się ono do zdań, w których powinny były wystąpić regularne formy czasy przeszłego, czyli zdań błędnych w zestawieniu z AGR i PLU, a nie jak miało to miejsce u B. Kirkici'a w odniesieniu do nieregularnych form czasu przeszłego. Niemniej na uwagę zasługuje fakt, że w obecnym badaniu formy fleksyjne tworzone za pomocą afiksacji, temat + sufiks, więc podlegające dekompozycji (AGR, PAST, PLU), były różnie przetwarzane. Wśród ww. form fleksyjnych PAST w zdaniach błędnych był przetwarzany wolniej niż AGR czy PLU. Podobna zależność nie została zaobserwowana w zdaniach poprawnych. Ze względu na fakt, że te trzy formy są tworzone w procesie afiksacji (temat + sufiks) w ich rozumieniu niezbędna jest dekompozycja, czyli świadomość tej dwuelementowej struktury. Jeżeli proces, dzięki któremu powstają AGR, PLU i PAST jak i ich struktura są takie same, co powoduje wolniejsze przetwarzanie zdań z błędnymi formami PAST? Czy oznacza to, że zrozumienie błędów PAST wymaga dłuższego czasu i większego zaangażowania kognitywnego? W przyszłych badaniach odpowiedzi na te pytania należy szukać nie tyle w strukturze czasu przeszłego ile w sposobie w jakim jest on przetwarzany.

\subsection{Zdania poprawne versus zdania błędne}


Średnie kumulatywne jak i średnie cząstkowe form poprawnych generowały wyższe wartości, czyli były przetwarzane dłużej we wszystkich kategoriach w obecnym badaniu: $d$ well time, liczba fiksacji i czas fiksacji. Co więcej, różnice pomiędzy formami poprawnymi i błędnymi we wszystkich ww. kategoriach były statystycznie znaczące. Przypomnijmy, że w eksperymencie uczestnicy byli poproszeni o przeczytanie ze zrozumieniem zdań błędnych i poprawnych. Poprawność tych zdań zależała jedynie od obecności formy fleksyjnej (np. -ed dla PAST, $-s$ dla AGR i PLU oraz 's dla POSS). Więc, tym, co powinni byli „zauważyć” uczestnicy był niewielki morfem. Fleksja w języku angielski ma postać małego elementu ortograficznego i jako taka może być trudna do uchwycenia. Nasi uczestnicy szybciej przetwarzali zdania błędne, czyli te zdania, w których brakowało form fleksyjnych. Jak gdyby błędy nie były zauważane, albo przynajmniej nie zawsze zauważane. Jeżeli w taki sposób zinterpretujemy wyniki badania, to tym samym stwierdzimy, że nasi uczestnicy byli gorsi w zauważeniu braku fleksji niż w przetworzeniu form fleksyjnych obecnych w zdaniach poprawnych. Wyniki wcześniejszych badań (zob. C.A. Miller/ L.B. Leonard/ D. Finneran 2008) dowodzą, że zauważenie braku jakiegoś elementu jest większym kognitywnym wysiłkiem niż zauważenie obecności tegoż elementu.

Możliwa jest również alternatywna interpretacja tych obserwacji; być może krótki czas fiksacji jest wynikiem tego, że uczestnicy szybko lokalizują błąd i nie starają się już zrozumieć błędnego zdania. Dlaczego w takim razie błędne formy są szybciej przetwarzane? Czyżby nasi uczestnicy unikali wysiłku kognitywnego związanego $\mathrm{z}$ niepoprawnym zdaniem? Może nawet zaawansowani uczniowie języka obcego nie zauważają wszystkich błędnych form ${ }^{3}$ ? Czy świadczy to o tym, że ich przetwarzanie morfosyntaktyczne nie jest w pełni zautomatyzowane jak to ma miejsce w przetwarzaniu tych form przez rodzimych użytkowników języka angielskiego? Być może problem ten w pewnym stopniu dotyczy samego procesu czytania. Sprawne przetworzenie zdania błędnego wymagałoby świadomości zasady stojącej za daną formą fleksyjną, zauważenia jej niezastosowania i przeprowadzenia reanalizy zdania. Stoimy na stanowisku, że niskie wartości fiksacji w zdaniach mogą świadczyć o braku bądź niedostatecznej reanalizie zdań. O tym, czy nasi uczestnicy

${ }^{3}$ Często rodzimi użytkownicy danego języka czytają błędne zdania tak jak gdyby były one poprawne. Dowodzi to istnienia mentalnych reprezentacji fleksji oraz automatycznej ich implementacji. Dotyczy to również tych rodzimych użytkowników, którzy utracili pełną zdolność posługiwania się językiem na skutek urazu mózgu (afazja Broki). W badaniu przeprowadzonym przez M. Szupica-Pyrzanowską (2009), anglojęzyczni pacjenci z afazją Broki zostali poproszeni o przeczytanie zdań zawartych $\mathrm{w}$ teście poprawności gramatycznej i o określenie czy zdania są błędne czy nie. Niektórzy z uczestników czytali na głos zdania z błędami fleksyjnymi tak jak gdyby były one poprawne, czyli tak jak gdyby zawierały końcówki fleksyjne. Niejednokrotnie to samo błędne zdanie czytane było trzy lub cztery razy zanim czytający ostatecznie podjął decyzję, co do jego poprawności. Obserwacje te skłaniają nas do dwojakiego rozumienia tego stanu rzeczy. Po pierwsze, problem ten może dotyczyć samego procesu czytania. Po drugie, poprawne czytanie błędnych zdań nie byłoby możliwe bez mentalnych reprezentacji fleksji. Nie możemy bezpośrednio odnieść tego do obecnego badania. Pośrednio jednak zauważamy, że istnieje konieczność bardzo skrupulatnego dobierania uczestników badań okulograficznych tak, aby wyeliminować np. dysleksję. 
rzeczywiście dostrzegali niepoprawność wszystkich błędnych zdań moglibyśmy się przekonać $\mathrm{w}$ badaniu okulograficznym połączonym $\mathrm{z}$ równoczesnym testem poprawności gramatycznej, w którym oprócz przeczytania zdań uczestnicy byliby również poproszeni o stwierdzenie czy przeczytane zdania są poprawne czy nie $\mathrm{i}$ dlaczego.

\subsection{Wiek, w którym rozpoczyna się naukę języka obcego}

Wyniki ankiety jaką wypełnili uczestnicy dowodzą, że rozpoczynali oni naukę języka angielskiego średnio w wieku 8-10 lat w kontekście języka obcego, a więc sporadycznie, co niewątpliwie wpływało na jakość nauki i częstotliwość kontaktu z tym językiem. Na przykład, jeżeli naukę języka drugiego (a więc takiego, którego uczy się w jego naturalnym środowisku) rozpoczyna się po okresie krytycznym, pełna automatyzacja gramatyki jest trudna do osiągniecia (zob. E. Bialystok 1997, Y.G. Butler/ K. Hakuta 2004). M. Ullman (2004) wykorzystujący do swoich obserwacji dane neurokognitywne zauważył, że jeżeli nauka języka drugiego rozpoczyna się w młodości lub wieku dojrzałym zdolność stosowania zasad gramatycznych stopniowo maleje. W przypadku form fleksyjnych, model M. Ullman’a zakłada, że zasada czasu przeszłego nie będzie obecna w repertuarze składniowym osób uczących się angielskiego, ponieważ nie będą one w stanie w sposób spójny rozłożyć na elementy składowe regularnie odmienianych czasowników w czasie przeszłym. W konsekwencji doprowadzi to do tego, że regularnie odmieniane czasowniki w czasie przeszłym będą zapamiętywane i przywoływane z pamięci jako odrębne elementy leksykalne podobnie jak ma to miejsce w przypadku nieregularnych form czasu przeszłego. Jednakże w innym miejscu M. Ullman przyznaje, że możliwym jest, aby uczniowie mogli mieć dostęp do zasad drugiego języka w wyniku większego doświadczenie z tymże językiem. Im większe doświadczenie w używaniu języka drugiego tym większy dostęp do jego zasad.

Ponadto H. Clahsen/ C. Felser (2006) sugerowali, że chociaż kompletny system gramatyki/ repertuar składniowy nie jest dostępny dla uczniów języka drugiego niezależnie od znajomości tego języka. Niektóre z zasad gramatyki są, co prawda bardziej podatne na automatyzację ponieważ są łatwiejsze, co przekłada się na ich "mechaniczne" używanie (a więc i rozumienie); do nich między innymi należy fleksja regularna odmiana. Wyodrębniając różne kategorie zasad gramatycznych H. Clahsen/ C. Felser nawiązali do M. Ullman'a (2004), który utrzymuje, że bardziej złożone zasady składniowe są niedostępne dla uczących się języka drugiego, podczas gdy automatyzacja zasad fleksyjnych jest możliwa, ale zależna jest od biegłości i stopnia znajomości języka, doświadczenia językowego, czy częstotliwości kontaktu z językiem.

\subsection{Kontekst nauczania języka drugiego/ obcego}

Kontekst nauczania nie stanowił przedmiotu badania jednak okazał się jego produktem ubocznym. Formalny (szkolny) kontekst nauczania języka obcego, a więc taki, który jest reprezentatywny dla populacji uczniów w obecnym badaniu, jest ilościo- 
wo i jakościowo odmienny od pozaszkolnego (naturalistycznego). Dlatego też końcowy efekt nauczania rozumiany jako stopień biegłości i znajomości języka będzie inny w obydwu kontekstach (zob. C. Muñoz 2008). Badania okulograficzne nad preferencjami zaawansowanych uczniów języka angielskiego jako języka drugiego dotyczącymi zdań podrzędnych dowiodły, że osoby uczące się angielskiego w kontekście pozaszkolnym używały zdań podrzędnie złożonych ze sprawnością porównywalną do tej jaką mają rodzimi użytkownicy angielskiego (zob. C. Frenck-Mestre 2002). Podobne wyniki uzyskali P.E. Dussias (2003) i P.E. Dussias/ N. Sagarra (2007), którzy dodatkowo zaobserwowali, że pozaszkolne i nieformalne środowisko wpływa nie tylko na strategie przetwarzania języka drugiego, ale również języka rodzimego. Wpływ środowiska nauczania na przetwarzanie morfosyntaktyczne jest niedostatecznie opracowany w literaturze (zob. C. Pliatsikas/ T. Marinis 2013). To, co wiemy na ten temat pochodzi przede wszystkim z badania przeprowadzonego przez K. Gor/ M.H. Long (2009) zajmujących się wpływem kontekstu formalnego na przyswajanie oraz przetwarzanie fleksji drugiego języka. Ich zdaniem kontekst szkolny może być pomocny jedynie w nauce form o niskiej częstotliwości używania lub w przyswajaniu regularnych zasad fleksyjnych jako że kontekst formalny jest niezależny od częstotliwości używania występujących w środowisku naturalnym, które kierują procesem uczenia się języka nierodzimego. Przetwarzanie form regularnych czasu przeszłego skutkuje dłuższym czasem reakcji niż przetwarzanie form nieregularnych (zob. B. Kirkici 2005). Nasi uczestnicy uczyli się w kontekście formalnym, czyli takim, który powinien sprzyjać przyswajaniu regularnych zasad charakteryzujących się wysoką częstotliwością występowania (np. czas przeszły) jednak pomimo tego przetwarzali niepoprawne formy czasu przeszłego krócej niż formy poprawne. Niewątpliwie sprawność w przetwarzaniu morfosyntaktycznym oparta na zasadach języka docelowego jest wypadkową wielu czynników, np. wysokiego poziomu biegłości, jakości kontaktu z językiem, jak również wieku, w którym rozpoczęło się naukę języka obcego/drugiego. Kwestia wpływu kontekstu na przetwarzanie morfosyntaktyczne w czasie rzeczywistym (online) cały czas jeszcze wymaga szczegółowo przygotowanych badań oraz rzetelnego opracowania w literaturze.

\subsection{Okulograf versus przetwarzanie morfosyntaktyczne}

W odpowiedzi na pytanie $\mathrm{nr} 3$, Czy okulograf jest właściwych narzędziem do zbadania przetwarzania morfosyntaktycznego i czy badanie okulograficzne może postużyć jako wskaźnik złożoności form fleksyjnych w języku angielskim? stwierdzamy, że w porównaniu z wcześniejszymi badaniami typu off-line, które nie doprowadziły do konsensusu w kwestii przetwarzania, złożoności i przyswajania angielskich form fleksyjnych, okulograf bez wątpienia zapewnia inną perspektywę badań i umożliwia wnikliwszą obserwację typu online. W tym względzie badania okulograficzne stanowią istotną metodę wspomagającą dotychczasowe badania behawioralne. W naszym badaniu obszary zainteresowania (areas of interest) stanowiły wyrazy, które zawierały bądź powinny były zawierać formy fleksyjne. Chociaż w badaniu wykorzystane były elementy leksykalne o dużej częstotliwości używania, częstotliwości jednak nigdy nie można w pełni wykluczyć jako zmiennej przeszkadzającej, szcze- 
gólnie, jeżeli bodźce przedstawione są w kontekście zdaniowym. Dlatego też, obserwacje uzyskane dzięki okulografowi powinno się jeszcze udoskonalić, na przykład przeprowadzając bardziej szczegółową analizę. W celu jej uzyskania należałoby wykorzystać oprogramowanie BeGaze Reading Package, które umożliwia analizę poszczególnych liter w wyrazie i tym samym zawęzić obszary zainteresowania do sufiksu $\mathrm{w}$ zdaniach poprawnych $\mathrm{i}$ do ostatniego segmentu czasowników/rzeczowników nieodmienionych. Wyniki analizy poszczególnych liter można docelowo porównać z wynikami analizy elementów leksykalnych.

\section{Konkluzja}

Pomimo że, nasze badanie miało charakter diagnostyczny, dało ono jednak asumpt do zastanowienia się nad formą przyszłych badań okulograficznych, których autorzy powinny pokusić się o próbę odpowiedzi na pytanie jak najlepiej wykorzystać badanie okulograficzne w celu np. pełniejszego zrozumienia przetwarzania morfosyntaktycznego. Bez wątpienia badania online mają ogromny potencjał jako metody wspomagające $\mathrm{w}$ badaniach kognitywistycznych czy neurolingwistycznych. Na koniec posłużymy się następującym przykładem: D. Tanner/ K. Inoue/ L. Osterhout (2014) wykorzystali potencjały wywołane (event related potentials) jako miarę do zbadania procesów uczenia się/utraty języka nierodzimego i zaobserwowali rozdźwięk pomiędzy danymi behawioralnymi (off-line) i danymi czasu rzeczywistego pochodzącymi z zapisu ERP. D. Tanner/ K. Inoue/ L. Osterhout (2014) zauważyli, że mózg wydawał się wiedzieć więcej niż sami uczestnicy. Chcemy się przekonać czy podobną zależność uzyskamy w badaniu składającym się z części behawioralnej off-line w formie testu poprawności językowej i przeprowadzonej miesiąc później na tych samych bodźcach części online, czyli badania okulograficznego. Zamierzamy dowiedzieć się czy i w tym względzie dane okulograficzne pozwolą na spekulacje dotyczące procesów kognitywnych zachodzących w mózgu.

\section{Bibliografia}

Andersen, R.W. (1978), An implicational model for second language research, (w:) Language Learning, 28, 221-281.

Arabatzi, M./ S. Edwards (2000), Functional categories in agrammatic speech, (w:) Brain and Language, 74, 539-541.

Arabatzi, M./ S. Edwards (2002), Tense and syntactic processes in agrammatic speech, (w:) Brain and Language, 80, 314-327.

Badecker, W./ A. Caramazza (1985), On considerations of method and theory governing the use of clinical categories in neurolinguistics and cognitive neuropsychology: The case against agrammatism, (w:) Cognition, 20, 97-125.

Bailey, N./ C. Madden/ S.D. Krashen (1974), Is there a natural sequence in adult second language learning? (w:) Language Learning, 24, 235-243.

Bastiaanse, R./ C.K. Thompson (2003), Verb and auxiliary movement in agrammatic Broca's aphasia, (w:) Brain and Language, 84, 286-305. 
Bayley, R. (1996), Competing constraints on variation in the speech of adult Chinese learners of English, (w:) R. Bayley, D. Preston (red.), Second language acquisition and linguistic variation. Amsterdam, 97-120.

Bialystok, E. (1997), The structure of age: in search of barriers to second language acquisition, (w:) Second Language Research, 13 (2), 116-137.

Bishop, D.V.M. (2013), Cerebral asymmetry and language development: cause, correlate or consequence? (w:) Science, 340, 1-22.

Booij, G. (2005), The grammar of words. Oxford.

Brandt, O./ B. Höhle (2009), Does production of verbal inflection precede comprehension? Evidence from Eyetracking. The Annual Meeting of the German Linguistics Society (DGfS) $4^{\text {th }}$ March 2009. Osnabrück.

Brown, R. (1973), A First Language: The Early Stages. Cambridge.

Butler, Y.G./ K. Hakuta (2004), Bilingualism and second language acquisition, (w:) T.K. Bathia, W.C. Ritchie (red.), The Handbook of Bilingualism. Blackwell, 114-144.

Carstairs-McCarthy, A. (2002), An introduction to English morphology. Edinburgh.

Cirillo, R. (2016), Why all John's Friends are Dutch, Not German: On the Determiner-Like Characteristics of the Inflection on the Universal Quantifier in West Germanic, (w:) Journal of Germanic Linguistics, 2016, 179-218.

Clahsen, H./ C. Felser (2006), Grammatical processing in language learners, (w:) Applied Psycholinguistics, 27 (1), 3-42.

de Villiers, J.G. (1974), Quantitative aspects of agrammatism in aphasia, (w:) Cortex, $1,36-54$.

den Dikken, M. (1998), Predicate Inversion in DP, (w:) A. Alexiadou/ C.Wilder (red.), Possessives, predicates and movement in the DP. Amsterdam, 177-214.

den Dikken, M. (2000), The syntax of features, (w:) Journal of Psycholinguistic Research, 29/ 1, 5-23.

Dulay, H.C./ M.K. Burt (1974), Natural sequences in child second language acquisition, (w:) Language Learinig, 24, 37-53.

Dussias, P.E. (2003), Syntactic ambiguity resolution in L2 learners, (w:) Studies in Second Language Acquisition, 25 (04), 529-557.

Dussias, P.E./ N. Sagarra (2007), The effect of exposure on syntactic parsing in Spanish- English bilinguals, (w:) Bilingualism: Language and Cognition, 10 (01), 101-116.

Enç, M. (1987), Anchoring conditions for tense, (w:) Linguistic Inquiry, 18, 633-658.

Epstein, S.D./ S. Flynn/ G. Martohardjono (1996), Second language acquisition. Theoretical and experimental issues in contemporary research, (w:) Behavioral and Brain Sciences, 19, 677-758.

Frenck-Mestre, C. (2002), An on-line look at sentence processing in the second language, (w:) J. Altarriba, R. Herridia (red.), Bilingual Sentence Processing. Amsterdam. Amsterdam etc., 218-236.

Goad, H./ L. White/ J. Steel (2003), Missing Surface Inflection in L2 acquisition: a prosodic account, (w:) B. Beachley et al. (red.) BUCLD 27 Proceedings. Somerville, 264-275. 
Goodglass, H./ L. Menn (1985), Is agrammatism a unitary phenomenon? (w:) M.-L. Kean (red.), Agrammatism (Perspectives in neurolinguistics, neuropsychology, and psycholinguistic). New York, 1-26.

Gor, K./ M.H. Long (2009), Input and second language processing, (w:) W.C. Ritchie, T.K. Bhatia (red.), The Handbook of second language acquisition, 445-472.

Greenberg, J.H. (1963), Some universals of grammar with particular reference to the order of meaningful elements, (w:) J.H. Greenberg (red.), Universals of language. Cambridge, 73-113.

Grodzinsky, Y. (2000), The neurology of syntax: language use without Broca's ar$e a$, (w:) Behavioral and Brain Sciences, 23 (1), 1-71.

Guéron, J./ T. Hoekstra (1995), The temporal interpretation of predication, (w:) A. Cardinaletti/ M.-T. Guasti (red.), Small clauses. San Diego.

Hawkins, R. (2000), Persistent selective fossilization in second language acquisition and the optimal design of the language faculty, (w:) Essex Research Reports in Linguistics, 34, 75-90.

Hopp, H. (2015), Semantics and morphosyntax in predictive L2 sentence processing, (w:) International Review of Applied Linguistics in Language Teaching, 53 (3), 277-306.

Jakobson, R. (1961), Aphasia as a linguistic problem (w:) S. Saporta/ J.E. Bastian (red.), Psycholinguistics: A book of readings. New York, 419-426.

Jakobson, R. (1968), Child language, aphasia and phonological universals. Hague/ Paris.

Jiang, N. (2004), Morphological insensitivity in second language processing, (w:) Applied Psycholinguistics, 25, 603-634.

Jiang, N. (2007), Selective integration of linguistic knowledge in adult second language learning, (w:) Language Learning, 57, 1-33.

Johnson, V.E./ J.G.de Villiers/ H.N. Seymour (2005), Agreement without understanding? The case of third person singular /s/ (w:) First Language, 25, 317-330.

Johnston, M. (1997), Development and variation in learner language (Doctoral thesis). Canberra.

Kaan, E. (2014), Predictive sentence processing in L2 and L1: What is different? (w:) Linguistic Approaches to Bilingualism, 4:2, 257-282.

Kean, M.-L. (1979), Agrammatism: A phonological deficit? (w:) Cognition, 5, 69-83.

Kirkici, B. (2005), Words and rules in L2 processing: an analysis of the dualmechanism model (unpublished MS). Ankara.

Klein, E.C./ I. Stoyneshka/ K. Adams/ T. Rose/ Y. Pugach/ S. Solt (2003), L2 Perception and Production of the English Regular Past: The Role of L1 and L2 Phonology, Poster presented at $27^{\text {th }}$ Annual BUCLD.

Lardiere, D. (1998a), Case and tense in the "fossilized steady-state, (w:) Second Language Research, 14 (1), 1-26.

Lardiere, D. (1998b), Dissociating syntax from morphology in a divergent end-state grammar, (w:) Second Language Research, 14, 359-375. 
Lardiere, D. (2000), Mapping syntactic features to forms in second language acquisition, (w:) J. Archibald (red.), Second Language Acquisition and Linguistics Theory. Oxford, 102-129.

Larsen-Freeman, D.E. (1976), An explanation for the morpheme acquisition order of second language learners, (w:) Language Learning, 26, 125-134.

Larson, C. (1998), Its Academic, or Is It?, (w:) V.P. Clark/ P.A. Eschholz/ A.F. Rosa (red.), Language. Readings in Language and Culture. St. Martin's.

Luk, Z.P./ Y. Shirai (2009), Review article: Is the acquisition order of grammatical morphemes impervious to L1 knowledge? Evidence from the acquisition of plural -s, articles, and possessive's, (w:) Language Learning, 59, 721-754.

Mace-Matluck, B.J. (1979), The order of acquisition of English structures by Spanish speaking children: Some possible determinants, (w:) R.W. Andersen (red.), The acquisition and use of Spanish and English as first and second languages. Washington, 75-89.

Menn, L./ L.K. Obler (1990), Agrammatic aphasia: a cross-language narrative source book. Amsterdam.

Miller, C.A./ L.B. Leonard/ D. Finneran (2008), Grammaticality judgments in adolescents with and without language impairment, (w:) International Journal of Language and Communication Disorders, 43 (3), 346-360.

Muñoz, C. (2008), Symmetries and Asymmetries of Age Effects in Naturalistic and Instructed L2 Learning, (w:) Applied Linguistics, 29 (4), 578-596.

Nuibe, Y. (1986), A report on the development of the grammatical morphemes inJapanese junior high school students learning English as a foreign language, (w:) Kyoiku Kagaku, 28 (2), 371-381.

O'Grady, W. (2006), The Problem of Verbal Inflection in Second Language Acquisition, (w:) Proceedings of the Pan-Pacific Association of Applied Linguistics, 1-21.

Perez-Leroux, A. (2005), Number problems in children, (w:) C. Gurski (red.), Proceedings of the 2005 Canadian Linguistics Association Annual Conference. (http://ling.uwo.ca/publications/CLA- ACL/CLA- ACL2005.htm)

Pica, T. (1983), Adult acquisition of English as a second language under different conditions of exposure, (w:) Language Learning, 33, 465-497.

Pinker, S. (1999), Words and rules. New York.

Pliatsikas, C./ T. Marinis (2013), Processing of regular and irregular past tense morphology in highly proficient second language learners of English: a self- paced reading study, (w:) Applied Psycholinguistics, 34 (5), 943-970.

Prèvost, P./ L. White (2000), Missing surface inflection or impairment in second language Acquisition, (w:) Second Language Research, 16, 103-133.

Quirk, R./ S. Greenbaum/ G. Leech/ J. Svartvik (1985), A comprehensive grammar of the English language (General Grammar Series). London. New York.

Radford, A./ M. Atkinson/ D. Britain/ H. Clahsen/ A. Spencer (2003), Linguistics. An Introduction. Cambridge.

Scott A./ D. Denison/ K. Börjars (2007), Is the English possessive 's truly a right edge phenomenon? ICLCE2, Toulouse.

Silva, R./ H. Clahsen (2008), Morphologically complex words in L1 and L2 processing: Evidence from masked priming experiments in English, (w:) Bilingual- 
ism: Language and Cognition, 11 (2), 245-260.

Szupica-Pyrzanowska, M. (2009), Morphological and Phonological Factors in the Production of Verbal Inflection in Adult L2 Learners of English and Patients with Agrammatic Aphasia ( $\mathrm{PhD}$ dissertation). New York.

Szupica-Pyrzanowska, M./ L.K. Obler/ G. Martohardjono (2016), Morphological vs. Phonological Explanations for Affix Errors in Agrammatism, (w:) Aphasiology, 30 (11), 1-23.

Tanner, D./ K. Inoue/ L. Osterhout (2014), Brain-based individual differences in online L2 grammatical comprehension, (w:) Bilingualism. Language and Cognition, 17, 77-293.

Ullman, M.T. (2004), Contributions of memory circuits to language: the declarative/procedural Model, (w:) Cognition, 92 (1-2), 231-270.

Wenzlaff, M./ H. Clahsen (2004), Tense and agreement in German agrammatism, (w:) Brain and Language, 89, 57-68.

White, L. (2003), Fossilization in steady state L2 grammars: persistent problems with inflectional morphology, (w:) Bilingualism: Language and Cognition, 6, $129-141$.

White, L. (2008), Some puzzling features of L2, (w:) J.M. Liceras, H. Zobl, H. Goodluck (red.), The Role of Formal Features in Second Language Acquisition. New York/ London.

Zobl, H./ J. Liceras (1994), Functional categories and acquisition orders, (w:) Language learning: A journal of research in language studies, 44 (1), 159-180.

Zwicky, A.M. (1987), Suppressing the Zs, (w:) Journal of Linguistics 23, 133-48.

\section{Bodźce}

\begin{tabular}{|l|l|}
\hline AGR (+) & AGR (-) \\
\hline comes & play \\
\hline plans & sleep \\
\hline goes & eat \\
\hline looks & arrive \\
\hline spends & bring \\
\hline corrects & give \\
\hline speaks & live \\
\hline works & cut \\
\hline gets & type \\
\hline
\end{tabular}

\begin{tabular}{|l|l|}
\hline PAST (+) & PAST (-) \\
\hline planted & promise \\
\hline talked & offer \\
\hline used & finish \\
\hline washed & return \\
\hline enjoyed & invite \\
\hline passed & burn \\
\hline visited & stop \\
\hline cooked & smoke \\
\hline refused & learn \\
\hline
\end{tabular}

\begin{tabular}{|l|l|}
\hline PLU (+) & PLU (-) \\
\hline nuts & student \\
\hline girls & school \\
\hline bags & tomato \\
\hline prices & dog \\
\hline seats & exercise \\
\hline cats & kid \\
\hline rooms & teenager \\
\hline movies & bird \\
\hline boys & mother \\
\hline
\end{tabular}

\begin{tabular}{|l|l|}
\hline POSS (+) & POSS (-) \\
\hline cat's food & uncle garden \\
\hline doctor's coat & son wife \\
\hline sister's dress & cousin name \\
\hline Mary's recipe & John house \\
\hline student's books & friend car \\
\hline school's team & father wife \\
\hline brother's patience & manager office \\
\hline Grandpa's bike & husband decision \\
\hline teacher's desk & aunt daughter \\
\hline
\end{tabular}

